\title{
Nutrient regimes control phytoplankton ecophysiology in the South Atlantic
}

\author{
T. J. Browning 1 , H. A. Bouman ${ }^{1}$, C. M. Moore ${ }^{2}$, C. Schlosser ${ }^{2}$, G. A. Tarran ${ }^{3}$, E. M. S. Woodward ${ }^{3}$, and \\ G. M. Henderson ${ }^{1}$ \\ ${ }^{1}$ Department of Earth Sciences, University of Oxford, South Parks Road, Oxford, UK \\ ${ }^{2}$ Ocean and Earth Science, National Oceanography Centre Southampton, University of Southampton, European Way, \\ Southampton, UK \\ ${ }^{3}$ Plymouth Marine Laboratory, Prospect Place, The Hoe, Plymouth, UK
}

Correspondence to: T. J. Browning (thomasb@earth.ox.ac.uk)

Received: 9 July 2013 - Published in Biogeosciences Discuss.: 17 July 2013

Revised: 18 December 2013 - Accepted: 19 December 2013 - Published: 30 January 2014

\begin{abstract}
Fast Repetition Rate fluorometry (FRRf) measurements of phytoplankton photophysiology from an acrossbasin South Atlantic cruise (as part of the GEOTRACES programme) characterised two dominant ecophysiological regimes which were interpreted on the basis of nutrient limitation. South of the South Subtropical Convergence (SSTC) in the northern sub-Antarctic sector of the Antarctic Circumpolar Current (ACC) in the Eastern Atlantic Basin, waters are characterised by elevated chlorophyll concentrations, a dominance by larger phytoplankton cells, and low apparent photochemical efficiency $\left(F_{\mathrm{v}} / F_{\mathrm{m}}\right)$. Shipboard $24 \mathrm{~h}$ iron $(\mathrm{Fe})$ addition incubation experiments confirmed that Fe stress was primarily responsible for the low $F_{\mathrm{v}} / F_{\mathrm{m}}$, with $\mathrm{Fe}$ addition to these waters, either within the artificial bottle additions or naturally occurring downstream enrichment from Gough Island, significantly increasing $F_{\mathrm{v}} / F_{\mathrm{m}}$ values. To the north of the SSTC at the southern boundary of the South Atlantic Gyre, phytoplankton are characterised by high values of $F_{\mathrm{v}} / F_{\mathrm{m}}$ which, coupled with the low macronutrient concentrations and increased presence of picocyanobacteria, are interpreted as conditions of Fe replete, balanced macronutrient-limited growth. Spatial correlation was found between $F_{\mathrm{V}} / F_{\mathrm{m}}$ and Fe:nitrate ratios, supporting the suggestion that the relative supply ratios of these two nutrients can control patterns of limitation and consequently the ecophysiology of phytoplankton in subtropical gyre and ACC regimes.
\end{abstract}

\section{Introduction}

The chlorophyll concentrations of the world's surface oceans are well constrained through satellite images of ocean colour. However, knowledge of the standing crop of phytoplankton is insufficient to understand the role of ocean primary production on global nutrient and carbon cycles, which will also be strongly influenced by the phytoplankton community structure and physiological status (Katz et al., 2004; Behrenfeld and Falkowski, 1997). In turn, the ecology and physiology of phytoplankton are regulated by multiple driving factors including light, temperature, nutrient availability, and grazing rates (Boyd et al., 2010). Globally, nutrient limitation of phytoplankton standing crops and growth rates has been shown to be dominated by the availability of fixed inorganic nitrogen, primarily in the form of nitrate, and iron (Fe) (Moore et al., 2013). However, the spatial resolution of data describing nutrient limitation is low, with large areas remaining poorly sampled (Moore et al., 2013). Such undersampling is partly a result of the effort involved in conducting, and difficulties in unambiguously interpreting, shipboard bioassay incubation experiments where the phytoplankton population has been removed from their in situ environment (Cullen et al., 1992; Moore et al., 2013). The physiological assessment of phytoplankton communities using Fast Repetition Rate fluorometry (FRRf) represents a possible means of rapidly diagnosing nutrient limitation of phytoplankton (Greene et al., 1994). However, a variety of factors can influence FRRf derived photophysiological parameters (e.g. 
the apparent photochemical efficiency, $\left.F_{\mathrm{v}} / F_{\mathrm{m}}\right)$ under multifaceted ecophysiological regimes (Behrenfeld et al., 2006; Moore et al., 2006a, 2008; Suggett et al., 2009; Schrader et al., 2011; Behrenfeld and Milligan, 2013). Thus, while many studies have suggested that FRRf signatures are influenced by nutrients, the prevailing light climate, and/or the phytoplankton community structure, the factors which dominate the signal under different circumstances remain a subject of debate (Suggett et al., 2009; Behrenfeld and Milligan, 2013).

Although the exact causative mechanisms remain to be fully established (Behrenfeld and Milligan, 2013), Fe additions to Fe-limited waters have been repeatedly shown to increase $F_{\mathrm{v}} / F_{\mathrm{m}}$ (Greene et al., 1994; Kolber et al., 1994; Behrenfeld et al., 1996; Olson, 2000; Boyd and Abraham, 2001; Sosik and Olson, 2002; Moore et al., 2006a, 2007). In contrast, in macronutrient-limited subtropical gyre waters $F_{\mathrm{v}} / F_{\mathrm{m}}$ values have typically been found to be higher than for Fe-limited waters and insensitive to nitrate and/or phosphate additions (Behrenfeld et al., 2006; Moore et al., 2008; see also Parkhill et al. (2001) for analogous laboratory experiments). The reasons for this differential response remain uncertain, although one possibility is that the phytoplankton in these waters are living under conditions of balanced nutrientlimited growth, rather than starvation, as a result of sustained nutrient (re-)supply due to rapid efficient recycling (Moore et al., 2008).

The South Subtropical Convergence (SSTC) is the intersection point of low macronutrient subtropical gyre waters and high macronutrient ACC waters and therefore represents one of the most dynamic nutrient environments in the oceans (Ito et al., 2005). Satellite images show chlorophyll concentrations in the SSTC are typically elevated with respect to subtropical gyre waters further north and Antarctic Circumpolar Current (ACC) waters to the south throughout the year, although peak concentrations are found during austral spring and summer (Longhurst, 1998). Suggested mechanisms explaining the enhanced phytoplankton standing crop of the SSTC principally revolve around the idea that convergence of subtropical gyre waters, generally considered to be limited by the availability of nitrate (e.g. Dugdale and Goering, 1967; Ryther and Dunstan, 1971; Eppley, et al., 1979), and ACC waters, generally considered to be limited by Fe availability (e.g. Boyd et al., 2000), provide both nitrate and Fe to the region, thus producing a nutrient regime that is capable of supporting elevated phytoplankton standing crops (Longhurst, 1998; Ito et al., 2005). The stability of the upper water column, critical for controlling water-column irradiance, has also been suggested as an important control of phytoplankton standing crop in the region. For example, the mixing of warm subtropical waters southwards across the SSTC has been suggested to provide thermal stability to the water column and therefore, through shallower mixing, increased light availability (Longhurst, 1998; Llido et al., 2005).

The current paper reports data on phytoplankton photophysiology and community structure from a South At-

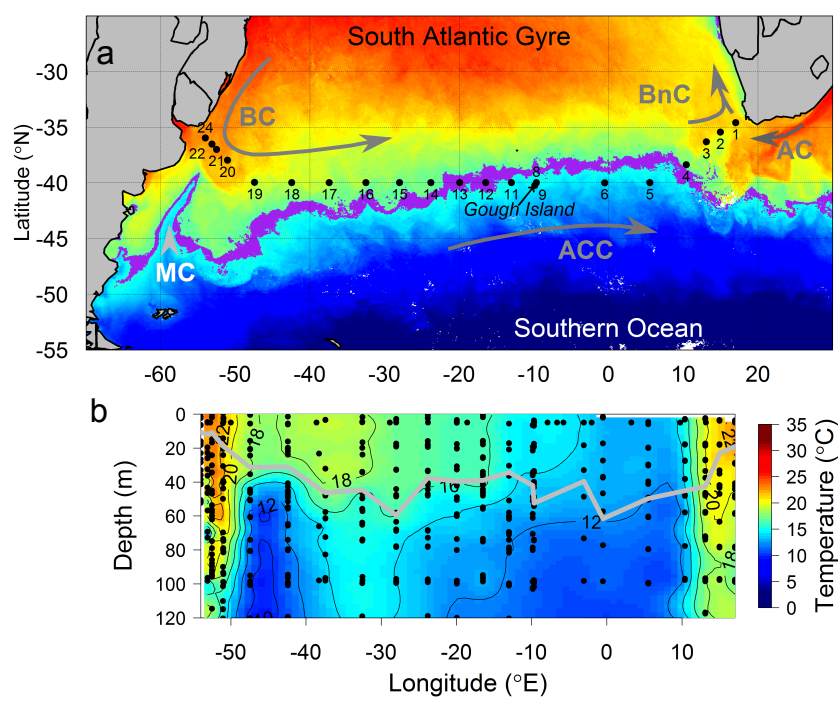

Fig. 1. Water temperature around the Atlantic SSTC. (a) MODIS monthly composite image of sea-surface temperature (SST) for January 2012. Dominant surface water masses and sampling stations are labelled (AC: Agulhas Current; ACC: Antarctic Circumpolar Current; BC: Brazil Current; BnC: Benguela Current; MC: Malvinas (Falklands) Current). Purple colouring represents SST $=16^{\circ} \mathrm{C}$ $\left( \pm 0.5^{\circ} \mathrm{C}\right)$ and is shown as a practical definition of the SSTC location. Gough Island is located next to Station 9. (b) Cross-basin section of CTD water temperature. Grey line indicates the mixed layer depth (MLD).

lantic cruise encountering strong gradients in nutrient environments during two crossings of the SSTC. These data, together with the results from a suite of $24 \mathrm{~h} F$ addition incubation experiments, offer an improved knowledge of the phytoplankton standing crop, community structure, and photophysiology in the region, in addition to providing strong field evidence for the dominant controls on FRRf signals in these regimes. The detailed sections of photophysiological parameters along the transect, together with supporting ancillary data, clearly demonstrate how the system is controlled by the contrasting conditions of low macronutrient, subtropical gyre-type waters and low $\mathrm{Fe}$, high macronutrient subAntarctic ACC waters.

\section{Methods}

\subsection{General}

\subsubsection{Cruises}

Data was collected on the RRS James Cook (JC068), as Section GA10 of the GEOTRACES programme. The cruise took place in mid-austral summer (28 December 2011 to 25 January 2012) and followed a track, mostly at $40^{\circ} \mathrm{S}$, occupying 21 stations between Cape Town, South Africa and Montevideo, South America (Fig. 1a). One station (Station 9) was 
occupied immediately to the east (i.e. downstream) of Gough Island - a volcanic island situated at $40.32^{\circ} \mathrm{S}, 9.92^{\circ} \mathrm{W}$.

\subsubsection{CTD data}

Vertical profiles of temperature, salinity, fluorescence and (occasionally) photosynthetically available radiation (PAR) were collected using a Seabird 911 CTD. Mixed-layer depths (MLD) were calculated using the threshold method of de Boyer Montégut et al. (2004). In this method, the MLD is identified as the depth at which density changes by a threshold value $\left(0.125 \mathrm{~kg} \mathrm{~m}^{-3}\right)$ relative to one at a near-surface reference depth $(10 \mathrm{~m})$. A linear interpolation between observed levels is then used to estimate the exact depth at which the difference criterion is met (de Boyer Montégut et al., 2004; Suga et al., 2004). Using this finite difference criterion has been shown to better represent the MLD compared to integral and regression methods (Thomson and Fine, 2003; de Boyer Montégut et al., 2004). The euphotic depth $\left(z_{\text {eu }}\right)$ was calculated from PAR profiles and is here defined as the depth at which PAR reduced to $1 \%$ of values at the surface. At stations where no PAR profiles were obtained, a correlation between chlorophyll and the diffuse attenuation coefficient $K_{\mathrm{d}}$ (calculated from profiles where PAR was collected) was used to estimate $K_{\mathrm{d}}$ and therefore $z_{\text {eu }}$ using $z_{\text {eu }}=4.6 / K_{\mathrm{d}}$. Continuous (every $10 \mathrm{~min}$ ) measurements of surface PAR were also made throughout the cruise by two $\mathrm{CM} 6 \mathrm{~B}$ pyranometers (Kipp and Zonen) mounted on ship.

\subsubsection{Remote sensing}

To examine the spatial and temporal variability in both chlorophyll $a$ and sea surface temperature (SST), and to monitor how the boundaries of the ACC and subtropical gyre provinces varied over the sampling period, satellite images from the Moderate Resolution Imaging Spectroradiometer (MODIS) were downloaded in daily, three day, eight day and monthly composite formats from the ocean colour website (http://oceancolor.gsfc.nasa.gov/).

\subsection{Nutrient concentrations}

\subsubsection{Macronutrients}

The dissolved macronutrients silicate, phosphate and nitrate + nitrite (hereafter simply referred to as nitrate) were analysed on-board ship using a micromolar Bran and Luebbe AAIII segmented flow, colorimetric autoanalyser with 4 analytical channels (nitrate+nitrite, nitrite, phosphate, silicate), using methods described in Woodward and Rees (2001). The results were checked against a certified nutrient reference material, made by KANSO Technos, Japan. Clean analytical, handling and sampling techniques were employed according to the GO-SHIP repeat hydrography manual (Hydes et al., 2010).

\subsubsection{Trace metal concentrations}

Surface seawater samples for trace metal analysis and incubation experiments were pumped from a towed fish at a depth of $2-3 \mathrm{~m}$. The seawater was pumped to a trace metal clean sampling container via a completely enclosed system with the suction provided by a Teflon diaphragm pump. Samples were filtered in-line through a $0.2 \mu \mathrm{m}$ cartridge filter (AcroPak $1000^{\mathrm{TM}}$ ) directly into acid cleaned low density polyethylene (LDPE) sample bottles. Discrete water samples from depth were obtained via $20 \mathrm{~L}$ Niskin sampling bottles deployed on a titanium frame CTD rosette using a Kevlar cable. Dissolved samples for trace metal analysis were collected after filtration through $0.2 \mu \mathrm{m}$ cartridge filters $\left(\right.$ AcroPak $\left.500^{\mathrm{TM}}\right)$, with slight overpressure provided by a clean air compressor.

Seawater samples for trace metal analysis were acidified with concentrated ultra-pure hydrochloric acid (Romil, UpA) to $\mathrm{pH} 1.6\left(0.023 \mathrm{M} \mathrm{H}^{+}\right)$, and shipped to the National Oceanography Centre (Southampton, UK). Trace metal samples were analysed under clean air conditions using a modified method previously outlined by Milne et al. (2010) using isotope dilution inductively coupled plasma mass spectrometry (ID-ICP/MS (Thermo Element $\mathrm{XR})$ ). To validate analysed sample concentrations, seawater standards (SAFe and GEOTRACES) were analysed with each batch of samples. Values agreed within the consensus values for SAFe and GEOTRACES (SAFe S: $0.09 \pm 0.03 \mathrm{nmol} \mathrm{Fe} \mathrm{kg}{ }^{-1}$ (consensus $0.09 \pm 0.01 \mathrm{nmol}$ Fe $\left.\mathrm{kg}^{-1}\right)$, GEOTRACES GS: $0.56 \pm 0.05 \mathrm{nmol} \mathrm{Fe} \mathrm{kg}^{-1}$ (consensus $0.52 \pm 0.07 \mathrm{nmol} \mathrm{Fe} \mathrm{kg}^{-1}$ )). The precision for replicate analyses was between 1-3\%. The manifold blank was $0.056 \pm 0.016 \mathrm{nmol} \mathrm{Fe} \mathrm{kg}{ }^{-1}$, and the limit of detection $(3 \times$ standard deviation of the blank) was determined to $0.032 \pm 0.020 \mathrm{nmol} \mathrm{Fe} \mathrm{kg}^{-1}$.

\subsection{Phytoplankton community structure}

\subsubsection{Accessory pigment composition}

Samples for High Performance Liquid Chromatography (HPLC) (0.5-2L) were filtered onto $0.7 \mu \mathrm{m}$ Whatman GF/F filters which were immediately flash-frozen in liquid nitrogen and then stored in $\mathrm{a}-80^{\circ} \mathrm{C}$ freezer. Pigments were extracted into $90 \%$ acetone by sonification and then analysed using a Thermo HPLC system following the method described in Gibb et al. (2000). Pigments were identified using diagnostic retention times and comparison of individual pigment absorption spectra from a known spectral library. Chlorophyll- $a$ and pigment mixture standards were included in each run to calibrate retention times for the accessory pigments.

Total accessory pigments ( $\sum \mathrm{AP}$ ) were defined in this study as the sum of: chlorophyll-c3, chlorophyllc2, peridinin, 19'-butanoyloxyfucoxanthin, fucoxanthin, 
$19^{\prime}$-hexanoyloxyfucoxanthin, prasinoxanthin, violoxanthin, diadinoxanthin, alloxanthin, zeaxanthin, lutein, gyroxanthin, chlorophyll $b$, divinyl chlorophyll $a$, and $\beta$-carotene. We found resultant concentrations to closely resemble chlorophyll $a$ biomass $\left(\sum \mathrm{AP}=\operatorname{chl} a+0.038, R^{2}=0.8\right)$ (Trees et al., 2000). Fractional contributions of individual diagnostic pigments to total accessory pigments were subsequently calculated.

\subsubsection{Phytoplankton absorption spectra}

Phytoplankton absorption samples were collected by filtering $0.5-1 \mathrm{~L}$ seawater onto $\mathrm{GF} / \mathrm{F}$ filters and flash-freezing the filter papers in liquid nitrogen before transfer to a $-80^{\circ} \mathrm{C}$ freezer for storage. Measurements were made using the hot methanol extraction method of Kishino (1985) using a Shimadzu UV-2550 spectrophotometer equipped with an integrating sphere over the visible range $(350-750 \mathrm{~nm})$. Optical densities for total (i.e. prior to methanol extraction) and detrital (after extraction) particles were corrected for optical pathlength amplification arising from scattering caused by the filter, according to the method of Cleveland and Weidemann (1993). Phytoplankton absorption coefficients $\left(a_{\mathrm{ph}}\right)$ were calculated by subtracting the detrital absorption spectra from the total absorption spectra. Pigment-specific absorption coefficients $\left(a_{\mathrm{ph}}^{*}\right)$ were calculated by dividing $a_{\mathrm{ph}}$ by the HPLC-determined chlorophyll $a$ concentration.

\subsubsection{Flow Cytometric Analysis}

Concentrations of nanophytoplankton, photosynthetic picoeukaryotes (PPEs), Synechococcus, Prochlorococcus, and total heterotrophic bacteria were analysed by analytical flow cytometry (AFC). Samples $(2 \mathrm{~mL})$ were fixed with neutralised paraformaldehyde (1\% final concentration) and left for $10 \mathrm{~min}$ in the dark at room temperature before being flashfrozen in liquid nitrogen. Samples were then transported and stored in a $-80^{\circ} \mathrm{C}$ freezer prior to $\mathrm{AFC}$ analysis.

Samples were thawed at room temperature and analysed using a FACSort flow cytometer (Becton Dickenson, Oxford, United Kingdom) according to the methods described in Davey et al. (2008) and Zubkov et al. (2003). An aliquot of sample $(500 \mu \mathrm{L})$ was stained with $50 \mu \mathrm{L}$ of $1 \%$ SYBR Green 1 DNA dye (SYBR Green diluted $100 \times$ in potassium citrate) for identification of total bacteria. Half of the remaining $1.5 \mathrm{~mL}$ was used for the purpose of identifying Synechoccocus, PPEs, and nanophytoplankton, and the other half for identifying Prochlorococcus. The FACsort instrument counted particles and measured chlorophyll fluorescence $(>650 \mathrm{~nm})$, orange fluorescence $(585 \pm 21 \mathrm{~nm})$, SYBR Green fluorescence, and side scatter (light scattered at 90 degrees to the plane of vertically polarised argon ion laser exciting at $488 \mathrm{~nm}$ ). Samples were analysed in duplicate for $3 \mathrm{~min}$ at a flow rate of $\sim 170 \mu \mathrm{L} \mathrm{min}^{-1}$ for counts of nanophytoplankton, PPEs, Synechococcus, and Prochloro- coccus. SYBR Green stained samples were analysed for $1 \mathrm{~min}$ at a flow rate of $\sim 60 \mu \mathrm{L} \mathrm{min}{ }^{-1}$ for counts of total bacteria.

Data analysis and cell counts were carried out in WinMDI Version 2.8 (Joseph Trotter) flow cytometry analysis software. Scatter plots of orange fluorescence versus red fluorescence were used to discriminate and enumerate Synechococcus from other pico- and nanophytoplankton, and plots of side scatter versus red fluorescence (with Synechococcus gated out) were used to enumerate PPEs and nanophytoplankton. Plots of side scatter versus orange fluorescence were then used to gate out Synechococcus from plots of side scatter versus red fluorescence which were then used to enumerate Prochlorococcus. Total bacteria were enumerated from plots of side scatter versus SYBR Green fluorescence.

\subsection{Fast Repetition Rate fluorometry}

A Fast Repetition Rate fluorometer (FRRf) (FAST ${ }^{\text {tracka II }}$ with integrated FAST $^{\text {act }}$ base unit, Chelsea Technologies Group Ltd.) was used to make measurements of phytoplankton photophysiology on samples from multiple depths in the euphotic zone. In a single acquisition protocol, the FRRf was set to deliver 64 sequences of one hundred $1 \mu \mathrm{s}$ saturation flashes at $1 \mu$ s intervals followed by twenty five $1 \mu$ s relaxation flashes at $84 \mu$ s intervals. Rapid Light Curves (RLC) were also run for all surface and subsurface chlorophyll maximum (SCM) samples. The RLC protocol was a series of identical FRRf single acquisitions (same settings as for single acquisitions, except sequences per acquisition were reduced to 32), performed under a series of 15 progressively higher PAR intensities ranging from 6-1434 $\mu \mathrm{mol}$ photons $\mathrm{m}^{-2} \mathrm{~s}^{-1}$ delivered from the integrated FAST ${ }^{\text {act }}$ system. Each illumination step in the RLC lasted for $180 \mathrm{~s}$, with 10 s dark steps in between.

Samples were dark-acclimated in opaque plastic bottles for at least $30 \mathrm{~min}$ prior to analysis and maintained at sea surface temperature by incubating in a water bath of flowing seawater from the ship's underway system. Blanks were run for the majority of samples using the following procedure (after Cullen and Davis, 2003): an aliquot of roughly $3 \mathrm{~mL}$ of sample was gently filtered using a $0.2 \mu \mathrm{m}$ pore size Nalgene syringe filter unit and a single acquisition FRRf measurement made using the same FRRf settings as the unfiltered sample. The average of fluorescence of a blank was taken (i.e. the mean fluorescence of 125 repetitions of the flash sequence). Minimal variable fluorescence was found in all sample blanks. All sample fluorescence values were subsequently blank-corrected by subtracting the blank from unfiltered samples before any further analysis.

Fluorescence transients were fit using the model of Kolber et al. (1998) in FASTpro (V1.5) software supplied with the instrument (Chelsea Technologies Group Ltd.). Parameter recovery using this software was checked against previous analysis methods performed in a MATLAB ${ }^{\mathrm{TM}}$ 
environment using custom codes (Laney, 2003; Moore et al., 2006b; Moore, unpublished). $F_{\mathrm{v}} / F_{\mathrm{m}}$ was calculated as $\left(F_{\mathrm{m}}-F_{\mathrm{o}}\right) / F_{\mathrm{m}}$ (where $F_{\mathrm{o}}$ is the fluorescence at the zeroth flashlet and $F_{\mathrm{m}}$ is the maximum fluorescence), with functional absorption cross sections $\left(\sigma_{\mathrm{PSII}}\right)$ recovered from the fit to the model of Kolber et al. (1998), effectively corresponding to the initial gradient of the fluorescence transients. The decline in fluorescence during relaxation flashes in the FRRf single acquisition protocol represents plastoquinone $Q_{\text {A }}$ re-oxidation in PSII, where the dominant decay component, $\tau_{\mathrm{QA}}$, represents the timescale of electron flow between plastoquinones A and B. Relative electron transport rates per RCII (ETR) were calculated from the RLC data using Eq. (1) (Gorbunov et al., 2001):

$\mathrm{ETR}=E \sigma_{\mathrm{PSII}}\left(\frac{F_{\mathrm{q}}{ }^{\prime} / F_{\mathrm{m}}{ }^{\prime}}{F_{\mathrm{v}} / F_{\mathrm{m}}}\right)$,

where $E$ is the ambient PAR intensity supplied by the FAST ${ }^{\text {act }}$ system, $F_{\mathrm{q}}^{\prime}=F_{\mathrm{m}}^{\prime}-F_{\mathrm{o}}^{\prime}$, and prime symbols indicate the measurements were made under actinic light. Calculated ETR's were then fitted to the following function (adapted from Platt et al., 1980):

$\frac{\mathrm{ETR}}{E}=\left(\frac{\mathrm{ETR}_{\max }}{E}\right)\left(1-e^{\left(\frac{-\alpha_{\mathrm{ETR}} E}{\mathrm{ETR}_{\max }}\right)}\right)$,

where $\mathrm{ETR}_{\max }$ represents the maximum light saturated ETR plateau and $\alpha_{\text {ETR }}$ represents the gradient of the light-limited slope and will effectively be proportional to $\sigma_{\text {PSII }}$. Normalisation of ETR to irradiance provides a more statistically robust fitting method (Silsbe and Kromkamp, 2012), particularly improving fit quality at high irradiance. The optimum light intensity $E_{k}$ was calculated as $\mathrm{ETR}_{\max } / \alpha_{\mathrm{ETR}}$.

\subsection{Incubation experiments}

Nine trace metal clean, $1 \mathrm{~L}$ polycarbonate bottles were filled with trace metal clean water either from the towed fish described previously or, for samples from the SCM, from the titanium frame CTD rosette (see Fig. 6a for depths). When sampling from the towed fish, bottles were filled close to midnight to avoid any effects of light stress on phytoplankton photophysiology. Three bottles were sub-sampled immediately for initial measurements of photophysiology and chlorophyll $a$ concentrations. For all experiments, samples for chlorophyll $a$ analysis ( $100 \mathrm{~mL}$ ) were filtered onto $0.7 \mu \mathrm{m}$ Whatman GF/F filter papers then extracted overnight in the dark in $10 \mathrm{~mL} 90 \%$ acetone in a $-20^{\circ} \mathrm{C}$ freezer, before measurement on a calibrated Trilogy fluorometer (Turner designs) following the method of Holm-Hansen et al. (1965). Of the remaining six bottles, 3 were spiked with $200 \mu \mathrm{L}$ $\mathrm{FeCl}_{3}$ in a $10 \% \mathrm{HCl}$ solution resulting in a final $\mathrm{Fe}$ concentration of $2 \mathrm{nmol} \mathrm{L}^{-1}$ and 3 bottles were sealed immediately with no amendment. The 3 amended and 3 control (non amended) bottles were sealed around the lids with
Parafilm ${ }^{\mathrm{TM}}$, double bagged, and placed in an on-deck incubator filled with continuously replenished sea-surface water from the ship's underway water system to limit temperature change of the samples. The incubator was shaded with blue screening to provide $35 \%$ of above surface irradiance.

After $24 \mathrm{~h}$ the bottles were sub-sampled for photophysiology and fluorometric chlorophyll $a$ concentration. Ironstressed waters were defined as those that produced a statistically significant $(p<0.01$ level using a one-tailed Student's $t$ test) $F_{\mathrm{v}} / F_{\mathrm{m}}$ increase in the Fe-amended bottles over that of the control (non-amended) bottles. Values of $\Delta F_{\mathrm{v}} / F_{\mathrm{m}}$ were calculated, where $\Delta F_{\mathrm{v}} / F_{\mathrm{m}}=$ average $F_{\mathrm{v}} / F_{\mathrm{m}} \mathrm{Fe}$ amended bottles - average $F_{\mathrm{v}} / F_{\mathrm{m}}$ control bottles (Ryan-Keogh et al., 2013). Chlorophyll $a$ concentrations were not expected to increase in response to the amendments, as $24 \mathrm{~h}$ is too short a period for phytoplankton to display a significant biomass increase in response to relief of nutrient limitation (e.g. Greene et al., 1992; Ryan-Keogh et al., 2013). The short duration of our bottle experiments will minimise significant changes in the taxonomic composition of the phytoplankton community during the incubation, resulting in $F_{\mathrm{v}} / F_{\mathrm{m}}$ differences likely being indicative of direct physiological changes only (Moore et al., 2008; Suggett et al., 2009; Ryan-Keogh et al., 2013).

Samples for macronutrients (nitrate, phosphate and silicate) and trace metals were taken prior to the bottle filling procedure described above, and for some experiments macronutrient samples were also sub-sampled for each of the three initial bottles. No samples for macronutrients were taken after the $24 \mathrm{~h}$ incubation period as previous studies have shown insignificant changes, even where $F_{\mathrm{v}} / F_{\mathrm{m}}$ responses are seen, due to the short nature of the incubation time (Ryan-Keogh et al., 2013). All sampling, sub-sampling, and Fe spiking was carried out using trace metal-clean techniques, either in a trace metal clean container on the ship or in a trace metal clean laminar flow hood in the ship laboratory (Fe spiking only).

\section{Results}

\subsection{General hydrography}

The SSTC can be traced almost continuously around the globe between $35^{\circ}-45^{\circ} \mathrm{S}$ and divides the anticyclonic circulation of the Southern Hemisphere gyres from the cyclonic circulation of the ACC. The convergence results in a region of strong downwelling and sharp surface temperature and salinity gradients (Fig. 1; Lutjeharms, 1985). The SSTC has been defined operationally as a band of elevated chlorophyll concentrations $\left(0.2-0.3 \mathrm{mg}\right.$ chlorophyll $a \mathrm{~m}^{-3}$, Longhurst, 1998), although this becomes poorly constrained in the western Atlantic. A more practical definition for the Atlantic sector of the SSTC is to use sea-surface temperature, with a contour of $16^{\circ} \mathrm{C}$ corresponding well to the nutrient gradients associated with the two water masses involved (Figs. 1 
and 2). The latitude of the SSTC is seasonally dependant, with flow rates of the Agulhas Current (AC) and the Brazil Current (BC) increasing in austral summer (Walker, 1986; Matano et al., 1993), resulting in a southward expansion of South Atlantic Gyre waters and a resultant southward shift in the SSTC. In the western basin, the southward shift in the intersection point of the BC and Malvinas Current (MC) (the $\mathrm{BC}-\mathrm{MC}$ confluence) in austral summer has been shown to be caused by an acceleration of water flow in the subtropical gyre and a weakened MC (Matano et al., 1993).

Mixed-layer depths showed consistent values of between $\sim 40-60 \mathrm{~m}$ throughout the central basin $\left(40^{\circ} \mathrm{W}\right.$ to $\left.15^{\circ} \mathrm{E}\right)$, reducing to $<25 \mathrm{~m}$ nearer South African and South American coasts (Fig. 1b). The light climate experienced by phytoplankton in the upper mixed layer is a function of the attenuation coefficient $\left(K_{\mathrm{d}}\right)$ (which in open ocean waters is mainly a function of phytoplankton biomass), the MLD, and above surface incident irradiance levels. Consequently, the lower $\mathrm{K}_{\mathrm{d}}$ values, the similar-to-shallower MLD's, and similar incident above surface irradiances would have resulted in higher light levels in sub-tropical gyre mixed layers than sub-Antarctic ones. For example, using two representative stations where rosette deployments included a PAR sensor in addition to the CTD package (Stations 5, representing subAntarctic waters, and 18, representing sub-tropical gyre waters) we calculated mean MLD irradiances using the method described in Venables and Moore (2010). For a fixed integrated daytime irradiance for both, calculated values showed the gyre-type mixed layer irradiance to be around double that for the station in sub-Antarctic waters.

\subsection{Nutrients}

\subsubsection{Macronutrients}

Concentrations of nitrate and phosphate were depleted $\left(<0.3 \mu \mathrm{mol} \mathrm{L}{ }^{-1}\right.$ nitrate $)$ in surface waters $(0-50 \mathrm{~m})$, and higher $\left(5-12 \mu \mathrm{mol} \mathrm{L}^{-1}\right.$ nitrate) at greater depths, apart from in the sub-Antarctic ACC waters south of the SSTC in the eastern basin where elevated concentrations $\left(\sim 5 \mu \mathrm{mol} \mathrm{L}{ }^{-1}\right.$ nitrate) were seen to extend into the surface waters (Fig. $2 \mathrm{a}$ and $\mathrm{b})$. Concentrations of silicate were uniformly low $\left(<1 \mu \mathrm{mol} \mathrm{L}{ }^{-1}\right)$ in surface waters $(0-50 \mathrm{~m}$ depth) apart from near the South American coast where concentrations increased markedly (Fig. 2c). For example, silicate concentrations reached $10 \mu \mathrm{mol} \mathrm{L}{ }^{-1}$ at $5 \mathrm{~m}$ depth at Station 22, and $22 \mathrm{mmol} \mathrm{L}^{-1}$ at Station 24 ( $2 \mathrm{~m}$ depth) in close proximity to the Plata River outflow. Silicate concentrations remained low in surface waters (0-50 m depth) near the South African coast, yet increased significantly at depths of greater than $\sim 50 \mathrm{~m}$ (reaching $7 \mu \mathrm{mol} \mathrm{L}-1$ at $60 \mathrm{~m}$ depth). A notable feature in the sections of nitrate and phosphate, and to a lesser extent silicate, were elevated concentrations at depths greater than $\sim 50 \mathrm{~m}$ for Stations $18-19$ around $45^{\circ} \mathrm{W}$. This feature also coincided with relatively colder waters (see Fig. 1b), and lower dissolved oxygen (not shown). This region of the transect was identified as being in a zone of depressed sea surface height (http://eddy.colorado.edu/ccar/data_viewer/index) for the time period of station sampling, suggestive of a cyclonic mesoscale eddy driving upwelling of deeper, colder, elevated nutrient waters.

\subsubsection{Micronutrients}

Surface dissolved Fe concentrations (DFe) showed low but variable surface concentrations throughout the cruise track (0.083-0.535 nmol L ${ }^{-1}$, Fig. 2d). Consistently low concentrations $\left(<0.16 \mathrm{nmol} \mathrm{L}^{-1}\right)$ were seen east of $10.5^{\circ} \mathrm{E}$ in the surface AC waters of the Eastern Atlantic. Sub-Antarctic ACC surface waters showed more variable concentrations, reaching a maximum of $0.348 \mathrm{nmol} \mathrm{L}^{-1}$ in Station 9 (proximal to Gough Island). On crossing the SSTC between Stations 13 and 14 (See Fig. 1a), a significant increase in DFe concentrations occurs, reaching a value of $0.501 \mathrm{nmol} \mathrm{L}^{-1}$ which is comparable to those in surface waters in close proximity to the South American coast. To the west of $33^{\circ} \mathrm{W}$ concentrations showed an increase towards the South American coast, with values reaching a maximum of $0.535 \mathrm{nmol} \mathrm{L}^{-1}$ in next to the Plata River.

\subsection{Chlorophyll- $a$ concentrations}

Satellite images show surface chlorophyll concentrations in the SSTC which are typically elevated with respect to waters further north (Southern Hemisphere subtropical gyres) and south (the ACC) throughout the year, although peak concentrations are found during austral spring and summer (September to February) (Fig. 3a-f). The band of elevated chlorophyll coinciding with the SSTC shows a southward shift in austral summer associated with increased AC and $\mathrm{BC}$ flow and a resultant southward expansion of the subtropical gyre (Fig. 3). In association with the trajectory of the SSTC (which occupies lower latitudes in the eastern basin than the western basin, Fig. 1a), the band of elevated chlorophyll concentrations is typically found further north in the eastern portion of the basin. For example, peak chlorophyll concentrations at $40^{\circ} \mathrm{S}$ for the austral spring-summer of 2011-2012 are seen in November 2011 for the western basin $\left(40^{\circ}-20^{\circ} \mathrm{W}\right)$ and February 2012 for the eastern basin $\left(10^{\circ} \mathrm{W}-10^{\circ} \mathrm{E}\right)$.

Profiles of chlorophyll $a$ concentrations revealed elevated and depth-uniform values $\left(0.2-0.7 \mathrm{mg} \mathrm{m}^{-3}\right)$ within the mixed layer for sub-Antarctic ACC waters in the central eastern basin, whilst low surface concentrations $\left(<0.2 \mathrm{mg} \mathrm{m}^{-3}\right)$ and elevated deep concentrations (typically $>0.4 \mathrm{mg} \mathrm{m}^{-3}$ and reaching a maximum of $1.46 \mathrm{mg} \mathrm{m}^{-3}$ ) are observed in the higher temperature regions of the western basin and nearer to the South African coast (Fig. 3a and b). Elevated mixed-layer chlorophyll $a$ concentrations are seen at 

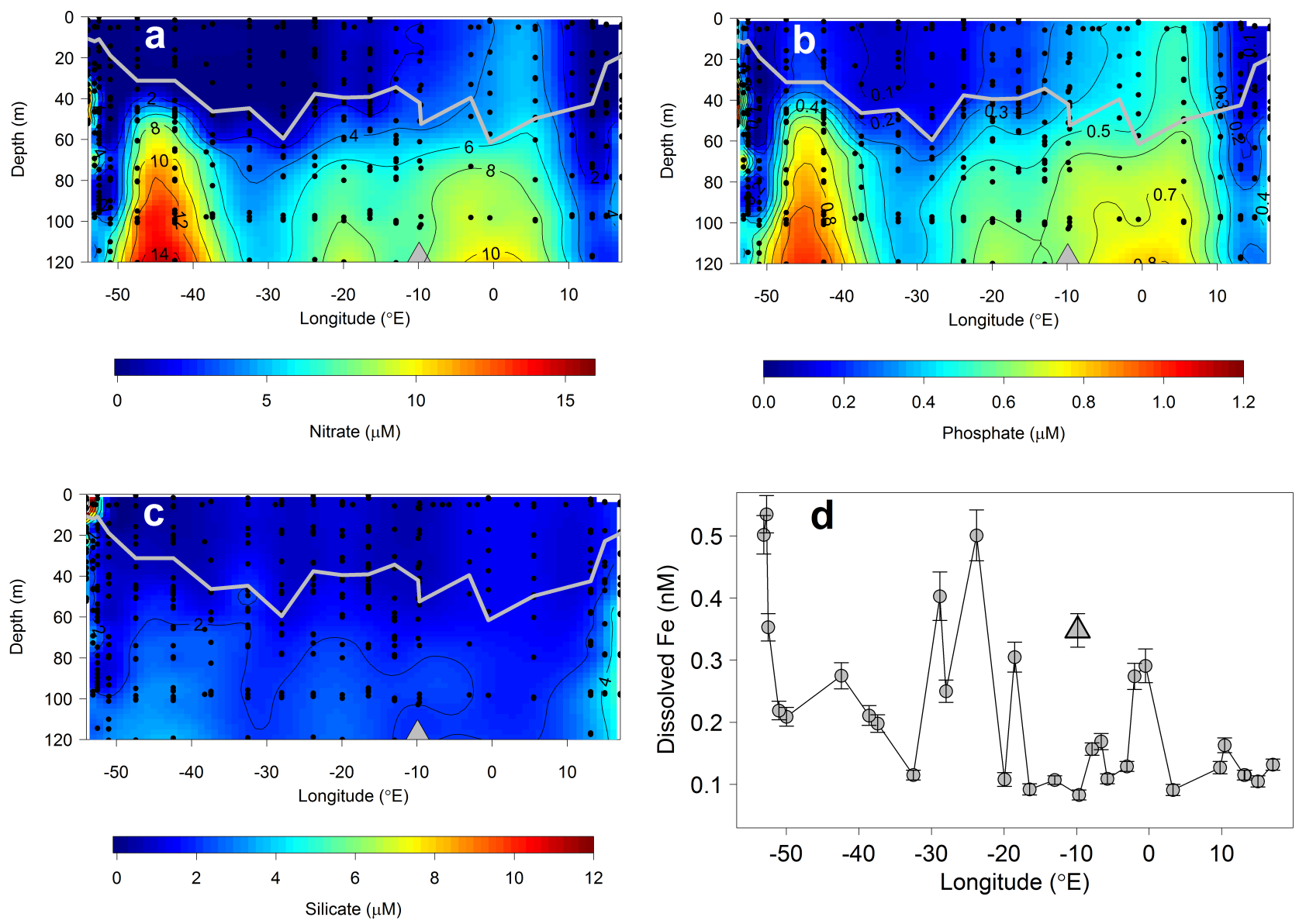

Fig. 2. Cross-basin section of macronutrient concentrations: (a) nitrate; (b) phosphate; (c) silicate. Grey lines indicate the MLD and grey triangles indicate the location of Gough Island. (d) Surface $(\sim 2-5 \mathrm{~m})$ dissolved Fe concentrations. Error bars represent the standard deviation calculated as the accuracy of the spike ratio $(\sim 4 \%)$ and the counting accuracy of the ICP-MS. The point labelled with a triangle represents the DFe concentration for Station 9 (next to Gough Island).

the station in close proximity to the Plata River $(\sim 0.7-$ $\left.0.9 \mathrm{mg} \mathrm{m}^{-3}\right)$.

\subsection{Phytoplankton community structure}

Specific absorption coefficients were low in the eastern basin in comparison with the rest of the transect (Fig. 4a), suggesting the presence of larger phytoplankton cells relative to the subtropical gyre-type regimes (Ciotti et al., 2002; Yentsch and Phinney, 1989). Correspondingly, AFC results showed higher concentrations of nanophytoplankton in the eastern basin (Fig. 4b). Elevated concentrations of smaller cells (picophytoplankton) are seen in these waters and at SCM depths in subtropical gyre-type waters, which also included elevated concentrations of Synechococcus and Prochlorococcus (Fig. 4d and e).

HPLC samples showed elevated 19' hexanoyloxyfucoxanthin $\left(19^{\prime}\right.$-Hex) contributions (Fig. $\left.5 \mathrm{~g}\right)$ in the eastern basin between $13^{\circ} \mathrm{E}$ to $10^{\circ} \mathrm{W}$ (generally $>40 \%$ contribution to total accessory pigment biomass) suggestive of haptophytes dominating phytoplankton communities in this region. However, 19'-Hex also contributed significantly to accessory pigments in the western basin and closer to the South African coast (e.g. $>30 \%$ contribution in SCM waters in AC waters of Stations 1 and 2, and generally greater than $20 \%$ in waters shallower than $80 \mathrm{~m}$ depth west of $10^{\circ} \mathrm{W}$ ), although the photoprotective pigment zeaxanthin (Fig. 5d), a diagnostic pigment of cyanobacteria, was also found to contribute significantly to the total pigment complement (up to $36 \%$ in surface waters of Station 1). Elevated contributions of divinyl chlorophyll $a$ (Fig. 5h) in some of these samples were indicative of Prochlorococcus, matching with elevated Prochlorococcus abundances measured by AFC (Figs. 4e and 5h). Elevated contributions of peridinin (Fig. 5a), the unambiguous marker pigment for dinoflagellates, were found in the eastern basin, yet its contribution to total accessory pigments generally remained only around $10 \%$ in this region. 

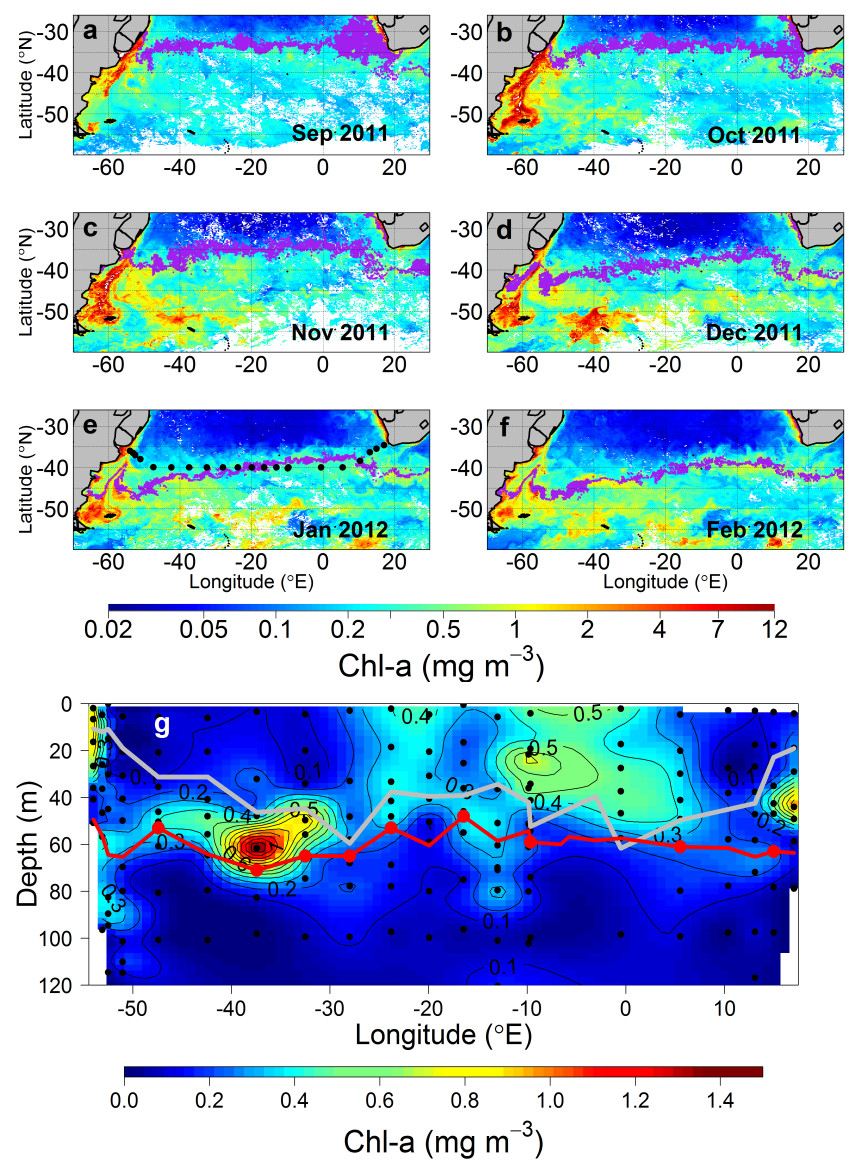

Fig. 3. MODIS monthly composite images (a-f) of chlorophyll $a$ concentrations for September 2011-February 2012 around the Atlantic SSTC. Sampling locations are labelled for the January 2012 image which was the month of in situ sampling. Purple colouring represents $\mathrm{SST}=16^{\circ} \mathrm{C}\left( \pm 0.5^{\circ} \mathrm{C}\right)$ and is shown as a practical definition of the SSTC location. (g) Cross-basin section of HPLCderived chlorophyll $a$ concentrations. Note the different scales for (a-f) and (g). Grey line is the MLD. The red line is the euphotic depth $\left(z_{\text {eu }}\right)$ here defined as the $1 \%$ light depth, with red dots indicating where direct PAR measurements were used to calculate the depth and remaining variability reflecting $z_{\text {eu }}$ estimated using a derived chlorophyll $a K_{\mathrm{d}}$ relationship $\left(K_{\mathrm{d}}=0.016\right.$ Chlorophyll $a+$ 0.068).

High contributions of the photoprotective pigment diadinoxanthin (reaching $17 \%$ contribution, Fig. 5b) were found in surface waters $(<50 \mathrm{~m}$ depth) across the whole transect, as has been observed in previous studies of haptophytedominated waters (e.g. Gibb et al., 2000, 2001). The highest fucoxanthin contributions (Fig. 5e) were observed in the stations furthest west along the cruise track within close proximity to the Plata River (up to $77 \%$ contribution at $40 \mathrm{~m}$ depth in Station 24), suggestive of diatoms dominating these waters. Elevated fucoxanthin contributions are also observed in the high macronutrient feature identified in Sect. 3.2.1 (reaching 50\% at $100 \mathrm{~m}$ depth at Station 18), which is suggestive of an increased contribution of diatoms to total chlorophyll biomass. However, as total chlorophyll $a$ biomass is very low in this region $\left(<0.1 \mathrm{mg} \mathrm{m}^{-3}\right.$, Fig. $\left.3 b\right)$, the actual biomass of diatoms would also be low. Similarly, elevated contributions of $19^{\prime}$-butanoyloxyfucoxanthin $\left(19^{\prime}\right.$ But) at depths below $\sim 60 \mathrm{~m}$ were observed across large parts of the transect, however the low chlorophyll concentrations at these depths indicated the total biomass of phytoplankton types containing this pigment (e.g. Chrysophyceae, Pelagophyceae) were relatively low.

\subsection{Phytoplankton photophysiology}

The section of $F_{\mathrm{v}} / F_{\mathrm{m}}$ in Fig. 6a shows strong variations in along-transect photophysiology, which again match up with the distinct regimes identified from previously described temperature, macronutrient, chlorophyll $a$ and phytoplankton community data. Low values of $F_{\mathrm{v}} / F_{\mathrm{m}}\left(F_{\mathrm{v}} / F_{\mathrm{m}}<0.3\right)$ are seen throughout the mixed layer in the sub-Antarctic ACC waters of the eastern basin with increases at greater depths. An exception to this is the station occupied next to Gough Island (Station 9), where elevated $F_{\mathrm{v}} / F_{\mathrm{m}}\left(F_{\mathrm{v}} / F_{\mathrm{m}}\right.$ $>0.3$ ) can be discerned throughout the mixed layer. Higher $F_{\mathrm{v}} / F_{\mathrm{m}}$ is seen at all depths in subtropical gyre-type waters in the western basin (west of $35^{\circ} \mathrm{W}$ ) and in AC waters $\left(>13^{\circ} \mathrm{E}\right)$. Off the South African coast, small but clear $F_{\mathrm{V}} / F_{\mathrm{m}}$ reductions occur at the SCM. Slightly more longitudinal variability was found in surface water $(<10 \mathrm{~m}) F_{\mathrm{v}} / F_{\mathrm{m}}$ values than for deeper samples. Values of $\sigma_{\text {PSII }}$ showed a less clear trend than $F_{\mathrm{V}} / F_{\mathrm{m}}$ (Fig. 6b), although a general trend of inverse co-variability with $F_{\mathrm{v}} / F_{\mathrm{m}}$ can be discerned (e.g. for 0 to $\left.50 \mathrm{~m}, R^{2}=0.3, p<0.001\right)$, with higher values generally seen in sub-Antarctic waters. Lowest $\sigma_{\text {PSII }}$ values were observed next to the South American coast. Trends in $1 / \tau_{\mathrm{QA}}$ were not clear, with significant depth and longitudinal variability (not shown). Despite this there was some indication of reduced values in ACC waters south of the SSTC.

RLC parameters again showed a less clear spatial trend than $F_{\mathrm{V}} / F_{\mathrm{m}}$, yet some broad characteristics of the different regions can be discerned (Fig. 6c and d). Surface samples from thermally-stratified subtropical gyre-type waters (west of $25^{\circ} \mathrm{W}$ and east of $10^{\circ} \mathrm{E}$ ) show higher $\mathrm{ETR}_{\max }$ and $E_{k}$ values than SCM samples. Particularly large differences, with highest recorded ETR max $_{\text {and }} E_{k}$ surface values, are observed for Stations 1 (nearest the South African coast), 19 and 20 (near the South American coast). Sub-Antarctic ACC waters south of the SSTC in the eastern basin show less variability between surface and SCM depths, and have ETR max $_{\text {}}$ and $E_{k}$ values in between that of the surface and SCM samples from subtropical waters. As expected, values of $\alpha_{\mathrm{ETR}}$ followed trends in $\sigma_{\text {PSII }}\left(R^{2}=0.53\right)$. 

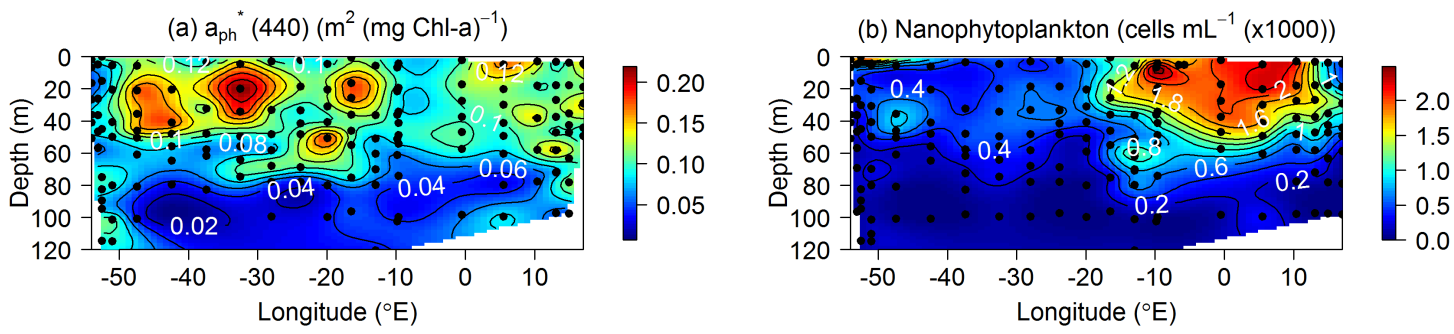

(c) Picophytoplankton (cells $\left.\mathrm{mL}^{-1}(\mathrm{x} 1000)\right)$



(d) Synechococcus (cells $\left.\mathrm{mL}^{-1}(\mathrm{x} 1000)\right)$

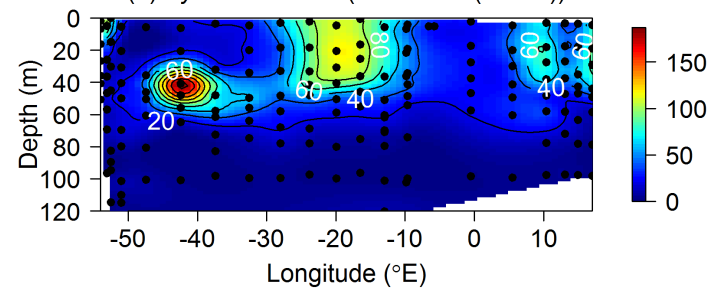

(e) Prochlorococcus (cells $\mathrm{mL}^{-1}(\mathrm{x} 1000)$ )
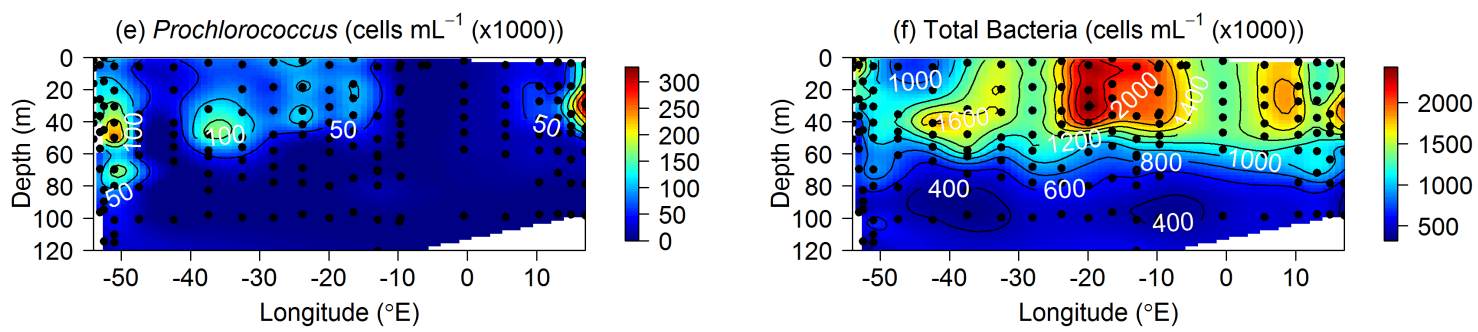

Fig. 4. Cross-basin (depth-longitude) sections of (a) specific phytoplankton absorption at $440 \mathrm{~nm}$, and analytical flow cytometry counts of: (b) nanophytoplankton; (c) picophytoplankton; (d) Synechococcus; (e) Prochlorococcus; (f) total bacteria.

\subsection{Fe addition experiments}

The Fe addition experiments showed clear $(t$ test $p<0.01)$ $F_{\mathrm{v}} / F_{\mathrm{m}}$ responses from $\mathrm{Fe}$-amended bottles over that of the control bottles for surface waters in the eastern basin between $10^{\circ} \mathrm{E}$ and $20^{\circ} \mathrm{W}$ (IF3 to IF8 in Fig. 7a-b). Within these experiments, a notable east-to-west reduction in response was observed in surface water amendments between IF3 and IF8 (e.g. $\Delta F_{\mathrm{v}} / F_{\mathrm{m}}$ values of 0.16 for IF3, decreasing to 0.063 for IF8). No significant $F_{\mathrm{v}} / F_{\mathrm{m}}$ response to Fe amendment was seen either side of this zone. Furthermore no statistically significant $F_{\mathrm{v}} / F_{\mathrm{m}}$ responses to $\mathrm{Fe}$ amendment were seen for the five SCM experiments conducted (Fig. 7b), although it should be noted that no SCM Fe-amendment experiments were conducted where the largest surface water responses were seen (IF3 to IF6). Significant changes in chlorophyll $a$ concentrations were also not observed in the majority of experiments.

\section{Discussion}

\subsection{Interpreting patterns of phytoplankton photophysiology in and around the SSTC}

The section of $F_{\mathrm{v}} / F_{\mathrm{m}}$ (Fig. 6a), together with ancillary chemical and phytoplankton data (Figs. 2-5) and the Fe incu- bation experiments (Fig. 7) demonstrates a clear division of this ocean section into two regimes: (1) low macronutrient, sufficient $\mathrm{Fe}$, and higher $F_{\mathrm{v}} / F_{\mathrm{m}}$ to the north of the SSTC; and (2) elevated macronutrient, insufficient $\mathrm{Fe}$, and lower $F_{\mathrm{v}} / F_{\mathrm{m}}$ to the south. Several factors are thought to control values of $F_{\mathrm{v}} / F_{\mathrm{m}}$, including light climate, the particular phytoplankton taxa present and the nutrient regime (Suggett et al., 2009). Using accessory pigment, AFC, irradiance and experimental data however, we can eliminate the first two controls and demonstrate that macronutrient and $\mathrm{Fe}$ availability govern the majority of variability in this parameter for our study region.

Light stress has been shown to result in photodamage to reaction centre proteins (e.g. Horton et al., 1996; Raven, 2011), or the down-regulation of PSII (e.g. Milligan et al., 2012). However, any resultant reductions in $F_{\mathrm{v}} / F_{\mathrm{m}}$ might be expected to reduce $F_{\mathrm{v}} / F_{\mathrm{m}}$ principally in the high irradiance surface of the stratified low macronutrient regions, rather than the ACC waters. Irrespectively light induced changes in $F_{\mathrm{v}} / F_{\mathrm{m}}$ would also not explain the observed differences in $F_{\mathrm{v}} / F_{\mathrm{m}}$ between experimental treatments (Fig. 7). The taxonomic composition of the phytoplankton community can potentially influence $F_{\mathrm{v}} / F_{\mathrm{m}}$ signatures, with a general trend of decreasing $F_{\mathrm{v}} / F_{\mathrm{m}}$ observed with decreasing cell size when grown under the same environmental conditions (Suggett et al., 2009). However, we performed correlation analysis be- 
Table 1. Simple linear regression statistics for potential controls on $F_{\mathrm{V}} / F_{\mathrm{m}}(0-50 \mathrm{~m})$ and $\Delta F_{\mathrm{V}} / F_{\mathrm{m}}$.

\begin{tabular}{|c|c|c|c|}
\hline $\begin{array}{l}\text { Potential controlling } \\
\text { variable for } F_{\mathrm{V}} / F_{\mathrm{m}}\end{array}$ & $\begin{array}{l}\text { Correlation } \\
\text { direction }\end{array}$ & $R^{2}$ & $p$ \\
\hline $\mathrm{DFe}$ & ns & 0.037 & ns \\
\hline Nitrate & negative & $0.12(0.38)$ & $\begin{array}{r}<0.0005 \\
(<0.0001)\end{array}$ \\
\hline DFe : nitrate & positive & $0.18(0.51)$ & $\begin{array}{r}<0.01 \\
(<0.0001)\end{array}$ \\
\hline Phosphate & negative & $0.17(0.33)$ & $\begin{array}{r}<0.0001 \\
(<0.0001)\end{array}$ \\
\hline Silicate & $\mathrm{ns}$ & 0.015 & ns \\
\hline Chlorophyll & $\mathrm{ns}$ & 0.022 & ns \\
\hline 19'-Hex: $\sum \mathrm{AP}$ & negative & 0.23 & $<0.0001$ \\
\hline Zeaxanthin: $\sum$ AP & positive & 0.22 & $<0.0001$ \\
\hline 19'-But: $\sum A \mathrm{AP}$ & ns & 0.00016 & ns \\
\hline Fucoxanthin: $\sum \mathrm{AP}$ & ns & 0.015 & ns \\
\hline$a_{\mathrm{ph}}^{*}(440)$ & $\mathrm{ns}$ & 0.041 & ns \\
\hline MLD & negative & 0.22 & $<0.0001$ \\
\hline Temperature & positive & 0.46 & $<0.0001$ \\
\hline Depth & positive & 0.040 & $<0.05$ \\
\hline
\end{tabular}

\begin{tabular}{llrr}
\hline $\begin{array}{l}\text { Potential controlling } \\
\text { variable for } \Delta F_{\mathrm{V}} / F_{\mathrm{m}}\end{array}$ & & \\
\hline$F_{\mathrm{V}} / F_{\mathrm{m}}$ & negative & 0.75 & 0.0001 \\
$\mathrm{DFe}$ & ns & 0.083 & $\mathrm{~ns}$ \\
Nitrate & positive & $0.59(0.79)$ & $<0.005$ \\
& & & $(0.0001)$ \\
DFe: nitrate & negative & $0.36(0.73)$ & 0.05 \\
& & & $(<0.0005)$ \\
\hline
\end{tabular}

Note "ns" = "not significant" $(p>0.05)$. Values in parenthesis are included for log transformation of the potential forcing variable where this significantly improved the correlation. $\mathrm{AC}=$ accessory pigments.

tween $F_{\mathrm{v}} / F_{\mathrm{m}}$ and indices of community structure for the upper $50 \mathrm{~m}$ water column depth which showed trends opposite to that expected from this control (Table 1). Significant negative correlations were found between $F_{\mathrm{v}} / F_{m}$ and the contribution of $19^{\prime}$-Hex to total accessory pigments, whilst a positive correlation was found between $F_{\mathrm{v}} / F_{m}$ and the contribution of zeaxanthin to total accessory pigments. This is indicative of lower $F_{\mathrm{v}} / F_{\mathrm{m}}$ being found in phytoplankton communities with higher haptophyte to cyanobacteria ratios, which is inconsistent with that expected under nutrient replete conditions (Suggett et al., 2009). Furthermore, in terms of the significant $F_{\mathrm{v}} / F_{\mathrm{m}}$ responses from the Fe-addition experiments in the ACC waters south of the SSTC (Fig. 7), net differential growth sufficient to generate taxonomic shifts in the bottles is unlikely over the short $24 \mathrm{~h}$ timescale (Moore et al., 2008; Ryan-Keogh et al., 2013), as evidenced by the generally insignificant changes in total chlorophyll $a$.

Laboratory studies have demonstrated that macronutrient starvation can lead to reductions in $F_{\mathrm{v}} / F_{\mathrm{m}}$ due to reduced reaction centre functionality (e.g. Kolber et al., 1988; Geider et al., 1993b). However, this type of nutrient stress actually appears rare in the open ocean (although see Kolber et al., 1990; Geider et al., 1993a), where more steady-state macronutrient stress appears to result in maintained $F_{\mathrm{v}} / F_{\mathrm{m}}$ values (MacIntyre et al., 1997; Parkhill et al., 2001; Behrenfeld et al., 2006; Kruskopf and Flynn, 2006; Moore et al., 2008; Schrader et al., 2011). The high $F_{\mathrm{v}} / F_{\mathrm{m}}$ values observed in waters with nitrate concentrations of less than $0.02 \mu \mathrm{mol} \mathrm{L}^{-1}$ are consistent with such an interpretation (Figs. $2 \mathrm{a}$ and $6 \mathrm{a}$ ). In contrast, Fe limitation both in terms of starvation and possibly steadystate limitation, has been observed to result in depressed values of $F_{\mathrm{v}} / F_{\mathrm{m}}$ which is relieved upon the addition of $\mathrm{Fe}$, both in culture (Geider et al., 1993b; Greene, 1991, 1992; Vassiliev et al., 1995; Sharader et al., 2011) and in situ (Greene, 1994; Kolber, 1994; Vassiliev et al., 1995; Behrenfeld, 1996; Olson, 2000; Boyd and Abraham, 2001; Sosik and Olson, 2002; Moore, 2007) although note that high $F_{\mathrm{v}} / F_{\mathrm{m}}$ was observed under steady-state Fe-limited diatom cultures by Peers and Price (2004). In a similar manner, our observations of $F_{\mathrm{V}} / F_{\mathrm{m}}$ recovery south of the SSTC after Fe enrichment (Fig. 7), together with a step-wise elimination of the other potential controls discussed above, allows us to confidently ascribe the observed low $F_{\mathrm{v}} / F_{\mathrm{m}}$ values to Fe stress.

Two mechanisms have been put forward to explain depressed $F_{\mathrm{v}} / F_{\mathrm{m}}$ values in Fe-limited waters. Firstly, as Fe is an essential component of the photosynthetic apparatus, its absence could potentially limit the functionality of PSII reaction centres (e.g. Greene et al., 1994; Kolber et al., 1994). However, more recent work has suggested that low $F_{\mathrm{v}} / F_{\mathrm{m}}$ values may originate from the production of excess disconnected light harvesting centres (DLHC) under conditions of Fe-limited growth (Behrenfeld et al., 2006; Schrader et al., 2011; Ryan-Keogh et al., 2012; Fraser et al., 2013). Excess pigments energetically uncoupled from a functional reaction centre will not contribute to photochemistry but could contribute to total fluorescence (i.e. increase $F_{\mathrm{o}}$ and $F_{\mathrm{m}}$ ), and hence reduce $F_{\mathrm{v}} / F_{\mathrm{m}}$ independently of $F_{\mathrm{v}}$ (Schrader et al., 2011; Ryan-Keogh et al., 2012). As such, depressed values of $F_{\mathrm{v}} / F_{\mathrm{m}}$ would characterise a Fe-stress physiological response, but without any coincident dysfunctionality of reaction centres or impairment of carbon fixation efficiencies (Behrenfeld and Milligan, 2013). Consequently, depressed $F_{\mathrm{v}} / F_{\mathrm{m}}$ in the sub-Antarctic waters south of the SSTC may still correspond to conditions of balanced $\mathrm{Fe}$ limitation of the phytoplankton standing crop, in a similar manner to the expected macronutrient limitation of waters to the north of the front.

The data collected in this study provides clear field evidence that high $F_{\mathrm{v}} / F_{\mathrm{m}}$ signatures can be produced in low $\mathrm{Fe}$ waters provided that coincident low macronutrient concentrations are found (compare Fig. 2a, b, d with Fig. 6a and also see Fig. 8). For example, AC waters in the east of the cruise track show $F_{\mathrm{v}} / F_{\mathrm{m}}>0.5$ yet $\mathrm{DFe}$ concentrations are less than $0.16 \mathrm{nmol} \mathrm{L}^{-1}$. There is some evidence from laboratory experiments that $\mathrm{Fe}$-macronutrient co-limited phytoplankton 
(a) Peridinin

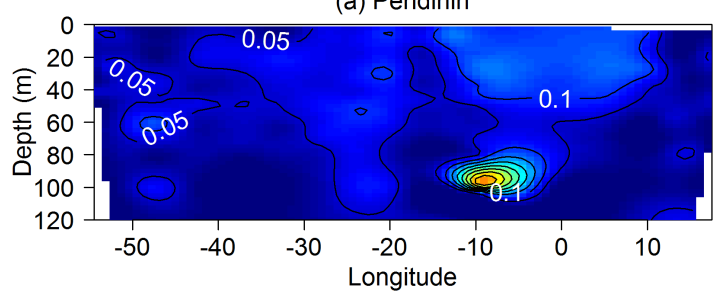

(c) 19 'But

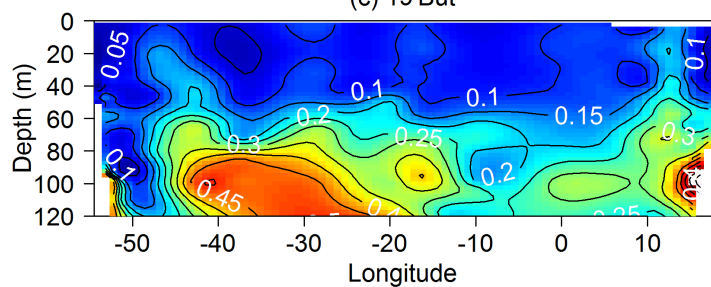

(e) Fucoxanthin

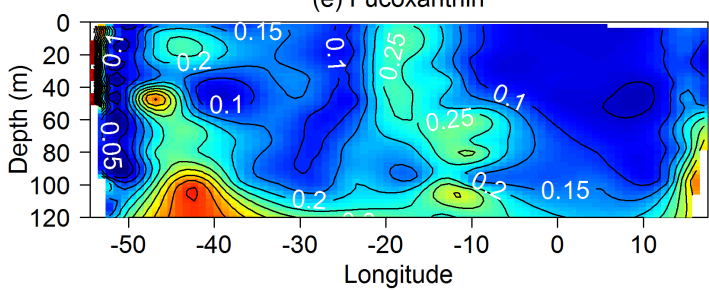

(g) 19 'Hex



(b) Diadinoxanthin

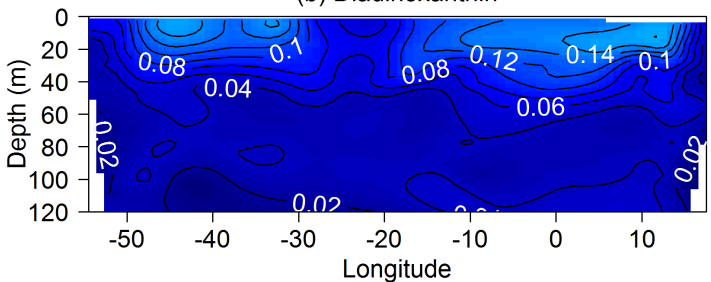

(d) Zeaxanthin

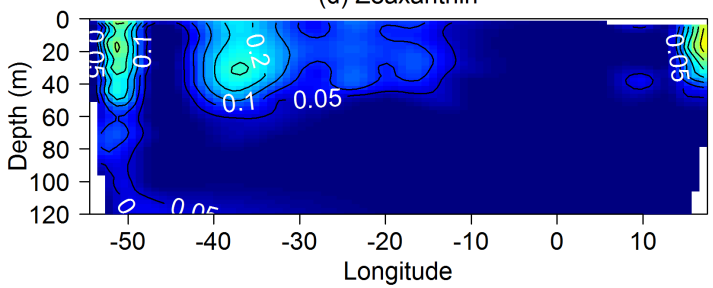

(f) Chlorophyll-b



(h) Divinyl Chlorophyll-a

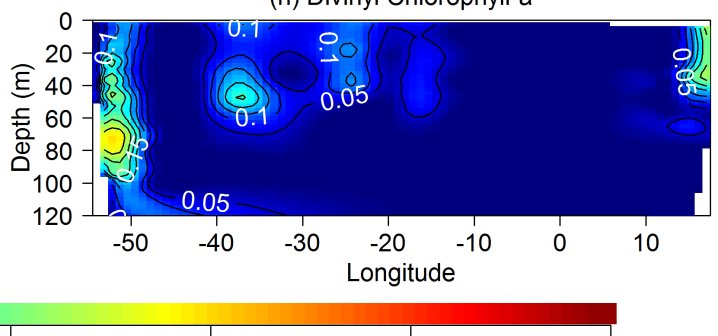

0.5

0.6

Fig. 5. Cross-basin (depth-longitude) sections of the contribution of major accessory pigments to total accessory pigments $\left(19^{\prime} \mathrm{Hex}^{\prime}=19^{\prime}-\right.$ hexanoyloxyfucoxanthin, $19^{\prime} \mathrm{But}=19^{\prime}$-butanoyloxyfucoxanthin).

show elevated $F_{\mathrm{v}} / F_{\mathrm{m}}($ Schrader et al., 2011). This observation together with subsequent $F_{\mathrm{V}} / F_{\mathrm{m}}$ reductions following macronutrient re-supply have been suggested to be due to the macronutrient requirement for DLHC synthesis (Schrader et al., 2011). With our current suite of experiments it is not possible to conclude whether or not the waters of the $\mathrm{AC}$ were Fe-macronutrient co-limited, although the addition of fixed nitrogen would likely have been required to stimulate any significant increase in the standing crop of phytoplankton.

More generally, these results also suggest that Fe-stressed conditions may not easily be identified solely on the basis of DFe concentrations (compare Fig. 2d with Fig. 6a, and also see Fig. 8). Measurements of DFe include soluble, colloidal, inorganic and ligand-bound fractions and considerable uncertainty persists as to the relative bioavailability of these fractions to phytoplankton (Shaked and Lis, 2012 and references therein). For the same measured DFe concentration, the ability for the available Fe to support the growth of the extant phytoplankton population might be expected to be higher in the subtropical gyre-type waters encountered compared with the ACC waters both as a result of the lower phytoplankton standing stock reducing competition for the metal and the generally smaller cell sizes increasing surfacearea-to-volume ratios and hence the kinetics of metal uptake (Hudson and Morel, 1990; Shaked et al., 2005).

Whilst at the level of an individual phytoplankton cell the factors controlling Fe limitation are complex, our data support suggestions that regions of Fe limitation are characterisable on the basis of the relative supply of DFe and nitrate (Parekh et al., 2005). Loss of Fe to scavenging in the deep ocean results in waters upwelling from depth (such as occurs strongly within the ACC) having lower DFe : nitrate ra- 

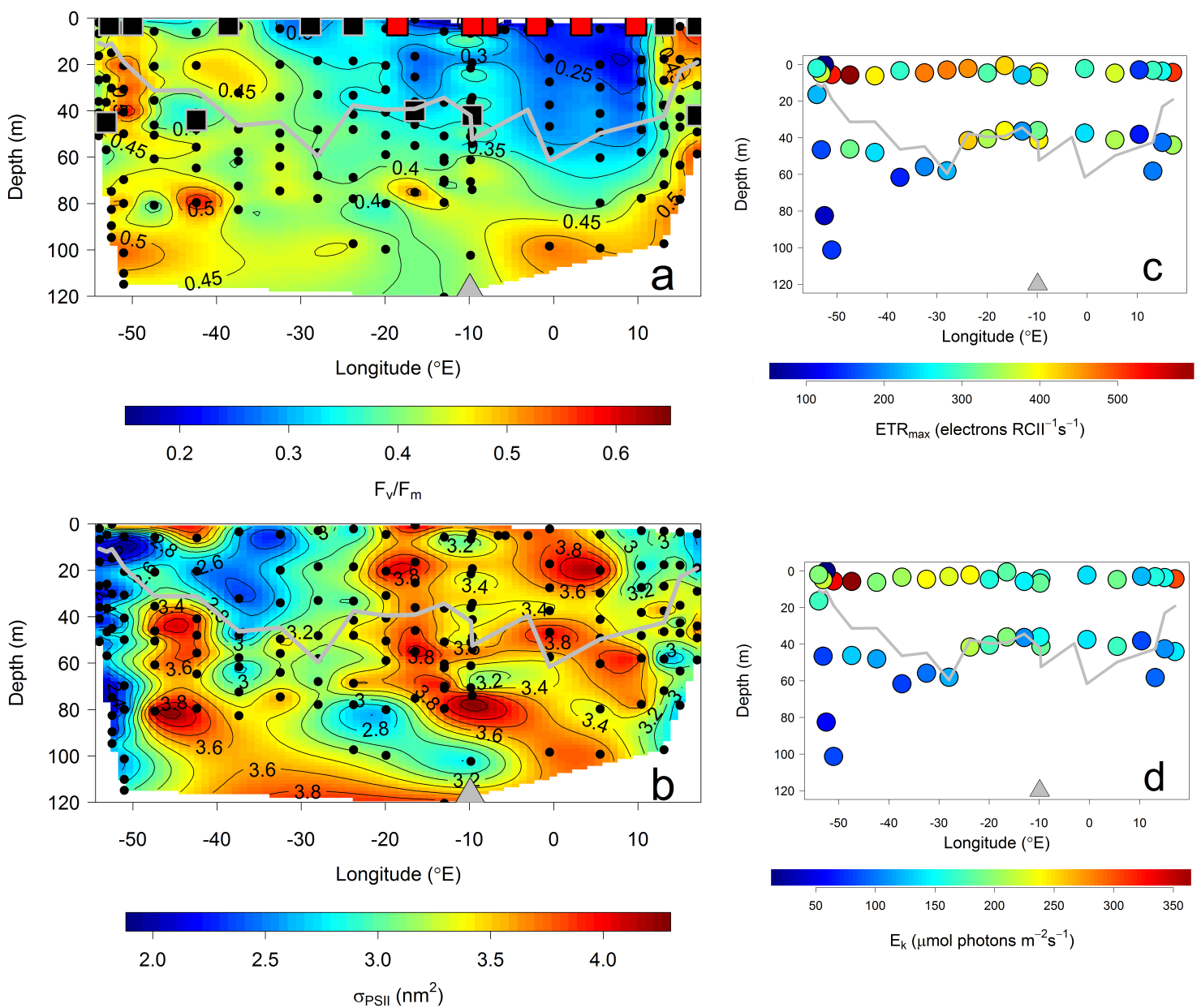

Fig. 6. Cross-basin sections of FRRf-derived photophysiological parameters: (a) $F_{\mathrm{V}} / F_{\mathrm{m}}$; (b) $\sigma_{\mathrm{PSII}}$; (c) relative ETR $\mathrm{E}_{\mathrm{max}}$; (d) $E_{k}$. Black and red squares in (a) indicate the location of $\mathrm{Fe}$ addition incubation experiments (black = no significant response from Fe amendment; red = statistically significant response). Grey lines indicate the MLD, grey triangles indicate the location of Gough Island.

tios than that of phytoplankton requirements (Johnson et al., 1997; Ito et al., 2005; Parekh et al., 2005; Sunda, 2012). Formation and subsequent export of organic material would therefore be expected to deplete Fe to levels that are limiting to phytoplankton growth in such regions. In contrast depletion of macronutrients under weaker replenishment from depth in subtropical gyre waters, alongside some level of external Fe supply (for example from dust), results in the gradual development of macronutrient limitation (Moore et al., 2013). Accordingly, across-transect values of the surface DFe : nitrate ratio suggested a good spatial correlation with both $F_{\mathrm{v}} / F_{\mathrm{m}}$, and the proximal response of the phytoplankton community to Fe replenishment as indicated by $\Delta F_{\mathrm{v}} / F_{\mathrm{m}}$, in our study region (Fig. 8). Moreover the degree of Fe stress showed a stronger spatial relationship with both $\mathrm{DFe}$ : nitrate and even nitrate than with DFe, with these relationships appearing nonlinear (shown visually in Fig. 8, and by simple linear regression in Table 1). Similarly Fe:macronutrient supply ratios effectively dictate the broad patterns of nutrient limitation which develop in regional (Ito et al., 2005) and global (Aumont et al., 2003; Moore et al., 2004) biogeochemical models. For example, the derived parameter $\mathrm{Fe}^{*}$, the difference between DFe and phosphate concentrations weighted by an assumed biological uptake ratio of the two nutrients $\left(R_{\mathrm{F}: \mathrm{P}}\right)$, has been used to delineate $\mathrm{Fe}$ or macronutrient limited regions (Ito et al., 2005; Parekh et al., 2005).

Values of $\sigma_{\text {PSII }}$ broadly show an inverse relationship to $F_{\mathrm{v}} / F_{\mathrm{m}}$ (Fig. 6b), potentially indicating either larger connected LHC's and/or less operational reaction centres per LHC under Fe stressed conditions (Vassiliev et al., 1995; Behrenfeld and Milligan, 2013). The less clear spatial pattern of $\sigma_{\mathrm{PSII}}$ than for $F_{\mathrm{v}} / F_{\mathrm{m}}$ may result from an enhanced taxonomic signature for this physiological trait (Suggett et al., 2004; Moore et al., 2005, 2006b; Suggett et al., 2009). RLC parameters showed a less clear across-transect trend than $F_{\mathrm{v}} / F_{\mathrm{m}}$, instead being dominated by vertical gradients within the gyre-type waters (see differences in parameters between surface water samples and below mixed layer depth 

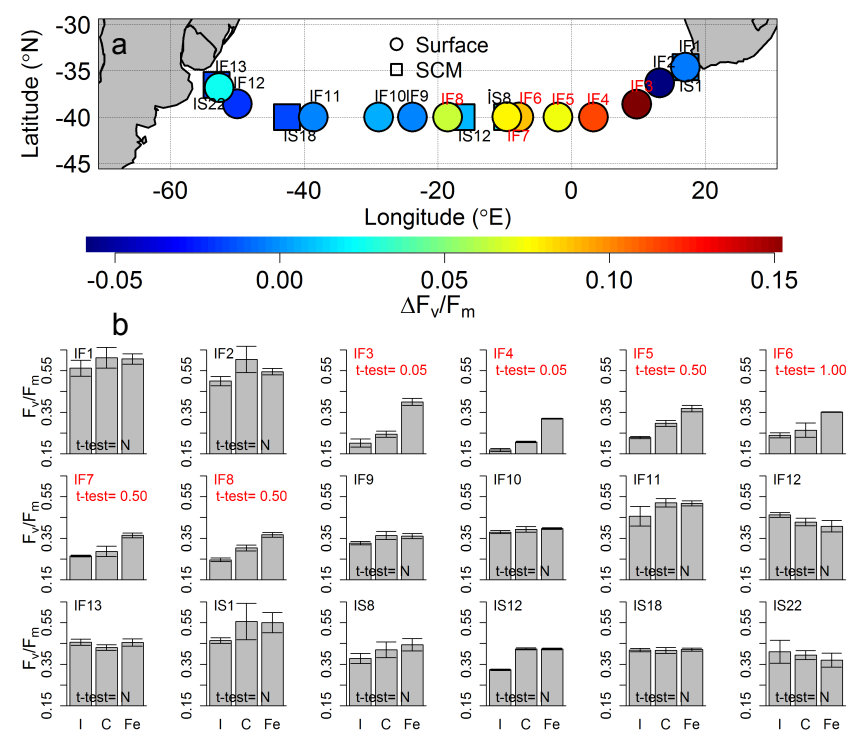

Fig. 7. Fe incubation locations and results. (a) Locations of experiments coloured according to $\Delta F_{\mathrm{V}} / F_{\mathrm{m}}$ values $\left(\Delta F_{\mathrm{V}} / F_{\mathrm{m}}=F_{\mathrm{V}} / F_{\mathrm{m}}\right.$ Fe amended bottle $-F_{\mathrm{V}} / F_{\mathrm{m}}$ control bottle) $. \mathrm{IF}=$ Incubation Fish (indicating trace-metal-clean tow-fish water used for the experiment, highlighted on the map as a filled circle), IS = Incubation Station (indicating SCM trace-metal-clean water from the titanium CTD rosette was used, highlighted on the map as a filled square). Experiments with statistically significant responses ( $t$ test $p<0.01$ ) are highlighted with red labels. (b) $F_{\mathrm{V}} / F_{\mathrm{m}}$ for incubation experiments. I = Initial, $\mathrm{C}=\mathrm{Control}$ (incubated for $24 \mathrm{~h}$ with no amendment), $\mathrm{Fe}=\mathrm{Fe}$ spiked (incubated for $24 \mathrm{~h}$ after $2 \mathrm{nmol} \mathrm{L}^{-1} \mathrm{FeCl}_{3}$ addition). Bars $=$ mean of three bottle replicates; error bars $=$ standard deviation. Student's one tailed $t$ test significance levels (\%) are shown, with significant results labelled in red $(\mathrm{N}=$ no significant difference between control and $\mathrm{Fe}$ amended bottles).

samples in Fig. 6c and d). This difference is likely related to photoacclimation, as the light environment phytoplankton are experiencing above and below the mixed layer is expected to be quite different. Specifically, elevated ETR $_{\max }$ and $E_{k}$ of surface samples compared to SCM samples (below the mixed layer) likely reflect acclimation to the increased irradiance encountered here (Moore et al., 2006b). In contrast, RLC parameters displayed less vertical variability between surface waters and those at the base of the mixed layer in ACC waters of the eastern basin: deep $(\sim 40 \mathrm{~m})$ and shallow $(\sim 5 \mathrm{~m})$ values of $\mathrm{ETR}_{\max }$ and $E_{k}$ were in between that of surface and SCM samples from the subtropical gyre-type regions to the east and west. Such a pattern likely resulted from these phytoplankton communities acclimating to mean mixed layer depth irradiances.

\subsection{Controls on the development of the SSTC bloom}

Satellite images suggest a band of elevated chlorophyll concentrations around the SSTC in austral summer (Fig. 3a-f). Note that the SSTC chlorophyll band can be distinguished

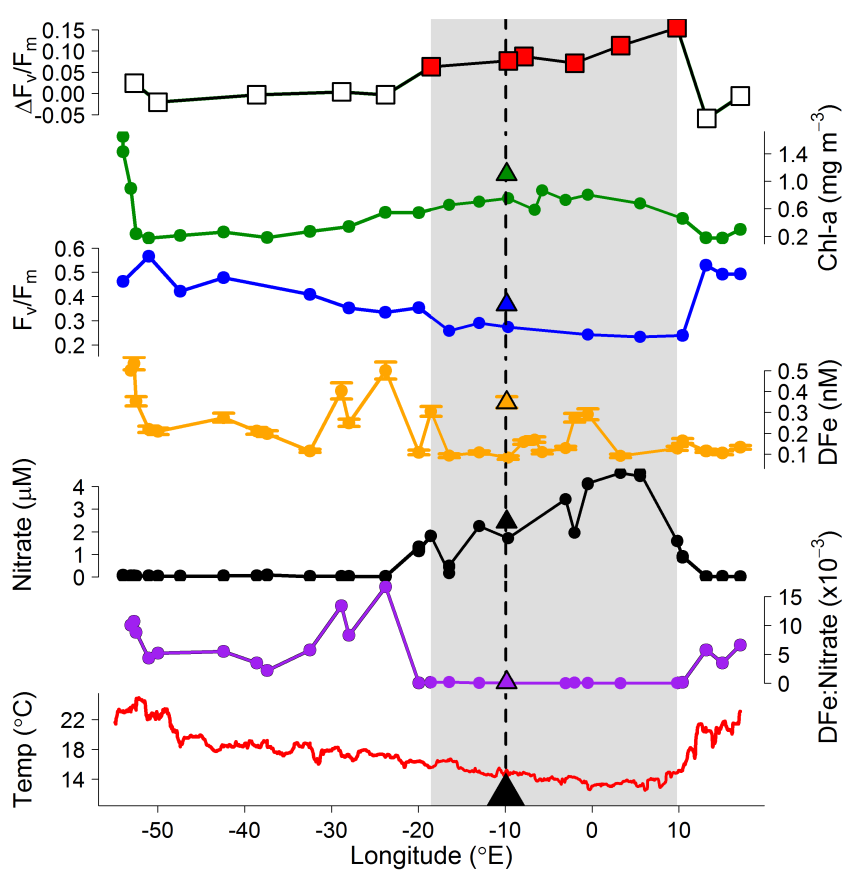

Fig. 8. Across-basin summary of: $\Delta F_{\mathrm{V}} / F_{\mathrm{m}}$ from $\mathrm{Fe}$ addition incubation experiments; chlorophyll $a ; F_{\mathrm{V}} / F_{\mathrm{m}}$; nitrate; DFe; $\mathrm{DFe}$ : nitrate; ship's underway temperature. All measurements are from the surface $\left(<10 \mathrm{~m}\right.$ depth) apart from $F_{\mathrm{V}} / F_{\mathrm{m}}$, shown for $20 \mathrm{~m}$ to reduce the influence of long-lived photodamage/PSII down-regulation on measurements. For $\Delta F_{\mathrm{v}} / F_{\mathrm{m}}$, red squares = statistically-significant response from $\mathrm{Fe}$ amended bottles. The grey shaded region highlights the Fe-limited zone as indicated by significant Fe amendment responses. Triangular symbols represent measurements from the station next to Gough Island, the location of which is highlighted by the large black triangle and dashed line.

from the Fe-fertilised band downstream of South Georgia and the Scotia Ridge further to the south (e.g. Sokolov and Rintoul, 2007; Moore and Abbott, 2002). Increasing chlorophyll concentrations are observed at the SSTC between September 2011 and February 2012 which could be a result of increased light availability through a combination of increased surface irradiance and reduced mixed-layer depths (de Boyer Montégut et al., 2004). However, as we have demonstrated, phytoplankton in these waters are limited by Fe availability in January 2012. Consequently the sustained and even increased chlorophyll into February 2012 may be indicative of a maintained Fe supply to this region.

The expected response of phytoplankton to natural Fe supply in these waters is particularly well demonstrated by $\mathrm{Fe}$ enrichment from Gough Island, which sits centrally in the Atlantic Basin at $40^{\circ} \mathrm{S}$ within the region of Fe-stress (Fig. 8). The eastward-flowing surface currents pass over the shallowsubsurface topography surrounding the island, and weathered material is presumably transported off the island by streams and as windblown dust. Evidence for Fe delivery to waters surrounding Gough Island comes from increased 
DFe, similar to other islands which have been hypothesised or shown directly to supply Fe to HNLC waters, for example the Crozet Islands (Planquette et al., 2007) and Kerguelen (Blain et al., 2001, 2002, 2007; Bucciarelli et al., 2001). Indeed, both elevated chlorophyll $a$ concentrations and a recovery of $F_{\mathrm{v}} / F_{\mathrm{m}}$ to higher values were observed for the single station occupied in the vicinity of Gough Island (Station 9), as might be expected upon relief of Fe limitation.

DFe was around 3-fold higher proximal to Gough Island than with the waters just to the north. Increases in $F_{\mathrm{v}} / F_{\mathrm{m}}$ and chlorophyll were more modest $(34 \%$ and $46 \%$, respectively), potentially reflecting the time required for phytoplankton entrained in the eastward flowing current to respond to Fe supply from Gough Island. For instance, the increase in $F_{\mathrm{v}} / F_{\mathrm{m}}$ between the two stations ( 8 and 9$)$ was comparable to the increase observed for the $24 \mathrm{~h}$ duration $\mathrm{Fe}$-amendment experiment using water collected at Station 8 (26\% increase for IF7, Fig. 7b). Moreover, there is no reason to suspect a linear correlation between Fe concentration and $F_{\mathrm{v}} / F_{\mathrm{m}}$ or chlorophyll (e.g. Cullen et al., 1992, also see Table 1 and Fig. 8). Similarly, there was relatively little indication of any significant species shifts accompanying the natural $\mathrm{Fe}$ fertilisation, with contributions of major diagnostic pigments remaining relatively constant (e.g. mixed layer fucoxanthin remained at $\sim 10 \%$ contribution for both stations). Although our data from Station 8 suggest Fe-fertilisation from Gough Island is spatially limited to the north, the downstream (longitudinal) Fe-fertilisation distance from Gough Island remains to be tested.

\section{Conclusions}

FRRf measurements of phytoplankton photophysiology alongside chlorophyll $a$ concentrations, community structure, macronutrients and DFe, together with results from a suite of $24 \mathrm{~h} \mathrm{Fe}$-addition incubation experiments from a cruise in the South Atlantic, have characterised two regimes on the basis of nutrient limitation. The primary limiting nutrient of the elevated chlorophyll, relatively larger celldominated sub-Antarctic ACC waters south of the SSTC in the Eastern Atlantic Basin in mid-austral summer has been shown to be Fe. Increasing Fe availability in this region results in increased $F_{\mathrm{v}} / F_{\mathrm{m}}$ values (bottle enrichment experiments and natural enrichment from Gough Island) and chlorophyll $a$ concentrations (natural enrichment from Gough Island). To the north of the SSTC, as seen close to the South African coast and in the western section of the cruise transect, the phytoplankton standing crop showed elevated $F_{\mathrm{v}} / F_{\mathrm{m}}$ and an enhanced contribution of smaller cells which are hypothesised to be limited by macronutrient availability.

Our results indicated poorer spatial correlation of DFe with values of $F_{\mathrm{v}} / F_{\mathrm{m}}$ than with $\mathrm{DFe}$ : nitrate ratios. Interestingly, the boundary between $\mathrm{Fe}$-stressed and non-stressed regions was associated with a $\mathrm{DFe}$ : nitrate ratio of between
$4 \times 10^{-4}$ and $5 \times 10^{-3} \mathrm{~mol}: \mathrm{mol}$, which is comparable with the extended average Redfield phytoplankton requirements of $\sim 1 \times 10^{-3} \mathrm{~mol}$ : mol (Quigg et al., 2011). Phytoplankton cells should not be directly sensitive to the local ratio of potentially limiting nutrients, responding rather to absolute availability (Moore et al., 2013). Consequently, as in other systems (Hutchins et al., 1998; Moore et al., 2006a; Ryan-Keogh et al., 2013) and theoretical studies (Parekh et al., 2005; Ito et al., 2005), the observed relationship of $\mathrm{Fe}$ stress with DFe: nitrate likely reflects large-scale controls on upper ocean nutrient limitation generated by gradients in relative nutrient supply ratios (Ito et al., 2005). Moreover, future work on physiological responses to changing nitrate availability under conditions close to those where $\mathrm{Fe}$ is potentially co-limiting (Ryan-Keogh et al., 2013) might allow further assessment of whether $F_{\mathrm{v}} / F_{\mathrm{m}}$ reductions following nitrate additions reflect co-limitation of phytoplankton by Fe and nitrate (Schrader et al., 2011) or simply a transition across a tipping point from nitrate to Fe limitation. Our results also suggested that other factors, including bioavailability, community structure, macronutrient availability and subsequent overall biological demand likely need to be considered alongside absolute DFe concentrations when assessing the potential for the development of regional Fe limitation. Such considerations may be particularly pertinent as the global coverage of DFe data increases rapidly though the GEOTRACES programme.

\section{Supplementary material related to this article is available online at http://www.biogeosciences.net/11/463/ 2014/bg-11-463-2014-supplement.zip.}

Acknowledgements. We thank the officers, crew, technicians and scientists of the RRS James Cook for their help on the UK-GEOTRACES JC068 cruise. We thank two anonymous reviewers who provided helpful comments which improved the manuscript. This work was funded by the UK-GEOTRACES National Environment Research Council (NERC) Consortium Grant (NE/H006095/1) which included a studentship to T. J. Browning.

Edited by: E. Marañón

\section{References}

Aumont, O., Maier-Reimer, E., Blain, S., and Monfray, P.: An ecosystem model of the global ocean including $\mathrm{Fe}$, $\mathrm{Si}, \mathrm{P}$ colimitations, Global Biogeochem. Cy., 17, 1060, doi:10.1029/2001gb001745, 2003.

Behrenfeld, M. J. and Falkowski, P. G.: Photosynthetic rates derived from satellite-based chlorophyll concentration, Limnol. Oceanogr., 42, 1-20, 1997. 
Behrenfeld, M. J. and Milligan, A. J.: Photophysiological expressions of iron stress in phytoplankton, Annual review of marine science, 5, 217-246, 2013.

Behrenfeld, M. J., Bale, A. J., Kolber, Z. S., Aiken, J., and Falkowski, P. G.: Confirmation of iron limitation of phytoplankton photosynthesis in the equatorial Pacific Ocean, Nature, 383, 508-511, 1996.

Behrenfeld, M. J., Worthington, K., Sherrell, R. M., Chavez, F. P., Strutton, P., McPhaden, M., and Shea, D. M.: Controls on tropical Pacific Ocean productivity revealed through nutrient stress diagnostics, Nature, 442, 1025-1028, 2006.

Blain, S., Treguer, P., Belviso, S., Bucciarelli, E., Denis, M., Desabre, S., Fiala, M., Jezequel, V. M., Le Fevre, J., Mayzaud, P., Marty, J. C., and Razouls, S.: A biogeochemical study of the island mass effect in the context of the iron hypothesis: Kerguelen Islands, Southern Ocean, Deep-Sea Res. Pt. I, 48, 163-187, 2001.

Blain, S., Sedwick, P. N., Griffiths, F. B., Queguiner, B., Bucciarelli, E., Fiala, M., Pondaven, P., and Treguer, P.: Quantification of algal iron requirements in the Subantarctic Southern Ocean (Indian sector), Deep-Sea Res. Pt. II, 49, 3255-3273, 2002.

Blain, S., Queguiner, B., Armand, L., Belviso, S., Bombled, B., Bopp, L., Bowie, A., Brunet, C., Brussaard, C., Carlotti, F., Christaki, U., Corbiere, A., Durand, I., Ebersbach, F., Fuda, J.L., Garcia, N., Gerringa, L., Griffiths, B., Guigue, C., Guillerm, C., Jacquet, S., Jeandel, C., Laan, P., Lefevre, D., Lo Monaco, C., Malits, A., Mosseri, J., Obernosterer, I., Park, Y.-H., Picheral, M., Pondaven, P., Remenyi, T., Sandroni, V., Sarthou, G., Savoye, N., Scouarnec, L., Souhaut, M., Thuiller, D., Timmermans, K., Trull, T., Uitz, J., van Beek, P., Veldhuis, M., Vincent, D., Viollier, E., Vong, L., and Wagener, T.: Effect of natural iron fertilization on carbon sequestration in the Southern Ocean, Nature, 446, 10701074, 2007.

Boyd, P. W. and Abraham, E. R.: Iron-mediated changes in phytoplankton photosynthetic competence during SOIREE, Deep-Sea Res. Pt. II, 48, 2529-2550, 2001.

Boyd, P. W., Watson, A. J., Law, C. S., Abraham, E. R., Trull, T., Murdoch, R., Bakker, D. C. E., Bowie, A. R., Buesseler, K. O., Chang, H., Charette, M., Croot, P., Downing, K., Frew, R., Gall, M., Hadfield, M., Hall, J., Harvey, M., Jameson, G., LaRoche, J., Liddicoat, M., Ling, R., Maldonado, M. T., McKay, R. M., Nodder, S., Pickmere, S., Pridmore, R., Rintoul, S., Safi, K., Sutton, P., Strzepek, R., Tanneberger, K., Turner, S., Waite, A., and Zeldis, J.: A mesoscale phytoplankton bloom in the polar Southern Ocean stimulated by iron fertilization, Nature, 407, 695-702, 2000.

Boyd, P. W., Strzepek, R., Fu, F. X., and Hutchins, D. A.: Environmental control of open-ocean phytoplankton groups: Now and in the future, Limnol. Oceanogr., 55, 1353-1376, 2010.

Bucciarelli, E., Blain, S., and Treguer, P.: Iron and manganese in the wake of the Kerguelen Islands (Southern Ocean), Mar. Chem., 73, 21-36, 2001.

Ciotti, A. M., Lewis, M. R., and Cullen, J. J.: Assessment of the relationships between dominant cell size in natural phytoplankton communities and the spectral shape of the absorption coefficient, Limnol. Oceanogr., 47, 404-417, 2002.

Cleveland, J. S. and Weidemann, A. D.: Quantifying absorption by aquatic particles - a multiple-scattering correction for glass-fiber filters, Limnol. Oceanogr., 38, 1321-1327, 1993.
Cullen, J. J. and Davis, R. F.: The blank can make a big difference in oceanographic measurements, Limnol. Oceanogr. Bull., 12, 2935, 2003.

Cullen, J. J., Yang, X., Macintyre, H. L.: Nutrient limitation of marine photosynthesis, in: Primary productivity and biogeochemical cycles in the sea, edited by: Falkowski, P. G. and Woodhead, A., Plenum, 69-88, 1992.

Davey, M., Tarran, G. A., Mills, M. M., Ridame, C., Geider, R. J., and La Roche, J.: Nutrient limitation of picophytoplankton photosynthesis and growth in the tropical North Atlantic, , Limnol. Oceanogr., 53, 1722-1733, 2008.

Dugdale, R. C. and Goering, J. J.: Uptake of new and regenerated forms of nitrogen in primary productivity, Limnol. Oceanogr., 12, 196-206, 1967.

Eppley, R. W. and Peterson, B. J.: Particulate organic-matter flux and planktonic new production in the deep ocean, Nature, 282, 677-680, 1979.

Fraser, J. M., Tulk, S. E., Jeans, J. A., Campbell, D. A., Bibby, T. S., Cockshutt, A. M.: Photophysiological and Photosynthetic Complex Changes during Iron Starvation in Synechocystis sp. PCC 6803 and Synechococcus elongatus PCC 7942, PLoS ONE, 8, e59861, doi:10.1371/journal.pone.0059861, 2013.

Geider, R. J., Greene, R. M., Kolber, Z., Macintyre, H. L., and Falkowski, P. G.: fluorescence assessment of the maximum quantum efficiency of photosynthesis in the Western North-Atlantic, Deep-Sea Res. Pt. I, 40, 1205-1224, 1993 a.

Geider, R. J., Laroche, J., Greene, R. M., and Olaizola, M.: Response of the photosynthetic apparatus of Phaeodactylumtricornutum (Bacillariophyceae) to nitrate, phosphate, or iron starvation, J. Phycol., 29, 755-766, 1993b.

Gibb, S. W., Barlow, R. G., Cummings, D. G., Rees, N. W., Trees, C. C., Holligan, P., and Suggett, D.: Surface phytoplankton pigment distributions in the Atlantic Ocean: an assessment of basin scale variability between 50 degrees $\mathrm{N}$ and 50 degrees S, Prog. Oceanogr., 45, 339-368, 2000.

Gibb, S. W., Cummings, D. G., Irigoien, X., Barlow, R. G., Fauzi, R., and Mantoura, C.: Phytoplankton pigment chemotaxonomy of the northeastern Atlantic, Deep-Sea Res. Pt. II, 48, 795-823, 2001.

Gorbunov, M. Y., Kolber, Z. S., Lesser, M. P., and Falkowski, P. G.: Photosynthesis and photoprotection in symbiotic corals, Limnol. Oceanogr., 46, 75-85, 2001.

Greene, R. M., Geider, R. J., and Falkowski, P. G.: Effect of iron limitation on photosynthesis in a marine diatom, Limnol. Oceanogr., 36, 1772-1782, 1991.

Greene, R. M., Geider, R. J., Kolber, Z., and Falkowski, P. G.: Ironinduced changes in light harvesting and photochemical energyconversion processes in eukaryotic marine-algae, Plant Physiol., 100, 565-575, 1992.

Greene, R. M., Kolber, Z. S., Swift, D. G., Tindale, N. W., and Falkowski, P. G.: Physiological limitation of phytoplankton photosynthesis in the Eastern Equatorial Pacific determined from variability in the quantum yield of fluorescence, Limnol. Oceanogr., 39, 1061-1074, 1994.

Holm-Hansen, O., Lorenzen, C. J., Holmes, R. W., and Strickland, J. D. H.: Fluorometric determination of chlorophyll, J. Cons. Perm. Int. Explor. Mer., 30, 3-15, 1965. 
Horton, P., Ruban, A. V., and Walters, R. G.: Regulation of light harvesting in green plants, Ann. Rev. Plant Phys., 47, 655-684, 1996.

Hudson, R. J. M. and Morel, F. M. M.: Iron transport in marine phytoplankton: Kinetics of cellular and medium coordination reactions, Limnol. Oceanogr., 35, 1002-1020, 1990.

Hutchins, D. A., DiTullio, G. R., Zhang, Y., and Bruland, K. W.: An iron limitation mosaic in the California upwelling regime, Limnol. Oceanogr., 43, 1037-1054, 1998.

Hydes, D. J., Aoyama, M., Aminot, A., Bakker, K., Becker, S., Coverly, S., Daniel, A., Dickson, A. G., Grosso, O., Kerouel, R., Van Ooijen, J., Sato, K., Tanhua, T., Woodward, E. M. S., and Zhang J. Z.: Determination of dissolved nutrients (N,P,Si) in seawater with high precision and inter-comparability using gas-segmented continuous flow analysers, The GO-SHIP Repeat Hyrography Manual: a collection of expert reports and guidelines; IOCCP report No. 14, ICPO publication series No. 134, version 1, 2010.

Ito, T., Parekh, P., Dutkiewicz, S., and Follows, M. J.: The Antarctic Circumpolar Productivity Belt, Geophys. Res. Lett., 32, L13604, doi:10.1029/2005g1023021, 2005.

Johnson, K. S., Gordon, R. M., and Coale, K. H.: What controls dissolved iron concentrations in the world ocean?, Mar. Chem., 57, 137-161, 1997.

Katz, M. E., Finkel, Z. V., Grzebyk, D., Knoll, A. H., and Falkowski, P. G.: Evolutionary trajectories and biogeochemical impacts of marine eukaryotic phytoplankton, Annu. Rev. Ecol. Evol. S., 35, 523-556, 2004.

Kishino, M., Takahashi, M., Okami, N., and Ichimura, S.: estimation of the spectral absorption-coefficients of phytoplankton in the sea, B. Mar. Sci., 37, 634-642, 1985.

Kolber, Z. S., Zehr, J., and Falkowski, P.: Effects of growth irradiance and nitrogen limitation on photosynthetic energy conversion in photosystem-II, Plant Physiol., 88, 923-929, 1988.

Kolber, Z. S., Wyman, K. D., and Falkowski, P. G.: Natural variability in photosynthetic energy-conversion efficiency - a field-study in the Gulf of Maine, Limnol. Oceanogr., 35, 72-79, 1990.

Kolber, Z. S., Barber, R. T., Coale, K. H., Fitzwater, S. E., Greene, R. M., Johnson, K. S., Lindley, S., and Falkowski, P. G.: Iron limitation of phytoplankton photosynthesis in the Equatorial PacificOcean, Nature, 371, 145-149, 1994.

Kolber, Z. S., Prasil, O., and Falkowski, P. G.: Measurements of variable chlorophyll fluorescence using fast repetition rate techniques: defining methodology and experimental protocols, BBABioenergetics, 1367, 88-106, 1998.

Kruskopf, M. and Flynn, K. J.: Chlorophyll content and fluorescence responses cannot be used to gauge reliably phytoplankton biomass, nutrient status or growth rate, New Phytol., 169, 525536, 2006.

Laney, S. R.: Assessing the error in photosynthetic properties determined by fast repetition rate fluorometry, Limnol. Oceanogr., 48, 2234-2242, 2003.

Llido, J., Garcon, V., Lutjeharms, J. R. E., and Sudre, J.: Event-scale blooms drive enhanced primary productivity at the Subtropical Convergence, Geophys. Res. Lett., 32, L15611, doi:10.1029/2005g1022880, 2005.

Longhurst, A. R.: Ecological Geography of the Sea. Academic Press, San Diego, 1998.
Lutjeharms, J. R. E.: Location of frontal systems between Africa and Antarctica - some preliminary results, Deep-Sea Res. Pt. A, 32, 1499-1509, 1985.

MacIntyre, J. G., Cullen, J. J., and Cembella, A. D.: Vertical migration, nutrition and toxicity in the dinoflagellate Alexandrium tamarense, Mar. Ecol.-Prog. Ser., 148, 201-216, 1997.

Matano, R. P.: On the separation of the Brazil Current from the coast, J. Phys. Oceanogr., 23, 79-90, 1993.

Milligan, A. J., Aparicio, U. A., and Behrenfeld, M. J.: Fluorescence and nonphotochemical quenching responses to simulated vertical mixing in the marine diatom Thalassiosira weissflogii, Mar. Ecol.-Prog. Ser., 448, 67-78, 2012.

Milne, A., Landing, W., Bizimis, M., and Morton, P.: Determination of $\mathrm{Mn}, \mathrm{Fe}, \mathrm{Co}, \mathrm{Ni}, \mathrm{Cu}, \mathrm{Zn}, \mathrm{Cd}$ and $\mathrm{Pb}$ in seawater using high resolution magnetic sector inductively coupled mass spectrometry (HR-ICP-MS), Analytica Chimica Acta, 665, 200-207, 2010.

Montegut, C. D., Madec, G., Fischer, A. S., Lazar, A., and Iudicone, D.: Mixed layer depth over the global ocean: An examination of profile data and a profile-based climatology, J. Geophys. Res.Oceans, 109, C102003, doi:10.1029/2004jc002378, 2004.

Moore, C. M., Lucas, M. I., Sanders, R., and Davidson, R.: Basinscale variability of phytoplankton bio-optical characteristics in relation to bloom state and community structure in the Northeast Atlantic, Deep-Sea Res. Pt. I, 52, 401-419, 2005.

Moore, C. M., Mills, M. M., Milne, A., Langlois, R., Achterberg, E. P., Lochte, K., Geider, R. J., and La Roche, J.: Iron limits primary productivity during spring bloom development in the central North Atlantic, Global Change Biol., 12, 626-634, 2006 a.

Moore, C. M., Suggett, D. J., Hickman, A. E., Kim, Y. N., Tweddle, J. F., Sharples, J., Geider, R. J., and Holligan, P. M.: Phytoplankton photoacclimation and photoadaptation in response to environmental gradients in a shelf sea, Limnol. Oceanogr., 51, 936-949, 2006b.

Moore, C. M., Seeyave, S., Hickman, A. E., Allen, J. T., Lucas, M. I., Planquette, H., Pollard, R. T., and Poulton, A. J.: Iron-light interactions during the CROZet natural iron bloom and EXport experiment (CROZEX) I: Phytoplankton growth and photophysiology, Deep-Sea Res. Pt. II, 54, 2045-2065, 2007.

Moore, C. M., Mills, M. M., Langlois, R., Milne, A., Achterberg, E. P., La Roche, J., and Geider, R. J.: Relative influence of nitrogen and phosphorus availability on phytoplankton physiology and productivity in the oligotrophic sub-tropical North Atlantic Ocean, Limnol. Oceanogr., 53, 291-305, 2008.

Moore, C. M., Mills, M. M., Arrigo, K. R., Berman-Frank, I., Bopp, L., Boyd, P. W., Galbraith, E. D., Geider, R. J., Guieu, C., Jaccard, S. L., Jickells, T. D., La Roche, J., Lenton, T. M., Mahowald, N. M., Marañón, E., Marinov, I., Moore, J. K., Nakatsuka, T., Oschlies, A., Saito, M. A., Thingstad, T. F., Tsuda, A., and Ulloa, O.: Processes and patterns of oceanic nutrient limitation, Nat. Geosci., 6, 701-710, doi:10.1038/ngeo1765, 2013.

Moore, J. K. and Abbott, M. R.: Surface chlorophyll concentrations in relation to the Antarctic Polar Front: seasonal and spatial patterns from satellite observations, J. Marine Syst., 37, 69-86, 2002.

Moore, J. K., Doney, S. C., and Lindsay, K.: Upper ocean ecosystem dynamics and iron cycling in a global threedimensional model, Global Biogeochem. Cy., 18, GB4028, doi:10.1029/2004gb002220, 2004. 
Olson, R. J., Sosik, H. M., Chekalyuk, A. M., and Shalapyonok, A.: Effects of iron enrichment on phytoplankton in the Southern Ocean during late summer: active fluorescence and flow cytometric analyses, Deep-Sea Res. Pt. II, 47, 3181-3200, 2000.

Parekh, P., Follows, M. J., and Boyle, E. A.: Decoupling of iron and phosphate in the global ocean, Global Biogeochemical Cy., 19, GB2020, doi:10.1029/2004gb002280, 2005.

Parkhill, J. P., Maillet, G., and Cullen, J. J.: Fluorescence-based maximal quantum yield for PSII as a diagnostic of nutrient stress, J. Phycol., 37, 517-529, 2001.

Peers, G. and Price, N. M.: A role for manganese in superoxide dismutases and growth of iron-deficient diatoms, Limnol. Oceanogr., 49, 74-83, 2004.

Planquette, H., Statham, P. J., Fones, G. R., Charette, M. A., Moore, C. M., Salter, I., Nedelec, F. H., Taylor, S. L., French, M., Baker, A. R., Mahowald, N., and Jickells, T. D.: Dissolved iron in the vicinity of the Crozet Islands, Southern Ocean, Deep-Sea Res. Pt. II, 54, 1999-2019, 2007.

Platt, T., Gallegos, C. L., and Harrison, W. G.: Photoinhibition of photosynthesis in natural assemblages of marine-phytoplankton, J. Mar. Res., 38, 687-701, 1980.

Quigg, A., Irwin, A. J., and Finkel, Z. V.: Evolutionary inheritance of elemental stoichiometry in phytoplankton, P. Roy. Soc. BBiol. Sci., 278, 526-534, 2011.

Raven, J. A.: The cost of photoinhibition, Physiol. Plantarum, 142, 87-104, 2011.

Ryan-Keogh, T. J., Macey, A. I., Cockshutt, A. M., Moore, C. M., and Bibby, T. S.: The cyanobacterial chlorophyll-binding protein IsiA acts to increase the in vivo effective absorption cross-section of PSI under iron limitation, J. Phycol., 48, 145-154, 2012.

Ryan-Keogh, T. J., Macey, A. I., Nielsdottir, M. C., Lucas, M. I., Steigenberger, S. S., Stinchcmbe, M. C., Achterberg, E. P., Bibby, T. S., and Moore, C. M.: Spatial and temporal development of phytoplankton iron stress in relation to bloom dynamics in the high-latitude North Atlantic Ocean, Limnol. Oceanogr., 58, 533-545, 2013.

Ryther, J. H. and Dunstan, W. M.: Nitrogen, phosphorous and eutrophication in coastal marine environment, Science, 171, 10081013, 1971.

Schrader, P. S., Milligan, A. J., and Behrenfeld, M. J.: Surplus Photosynthetic Antennae Complexes Underlie Diagnostics of Iron Limitation in a Cyanobacterium, Plos One, 6, e18753, doi:10.1371/journal.pone.0018753, 2011.

Shaked, Y. and Lis, H.: Disassembling iron availability to phytoplankton, Front. Microbiol., 3, 123, doi:10.3389/fmicb.2012.00123, 2012.

Shaked, Y., Kustka, A. B., and Morel, F. M. M.: A general kinetic model for iron acquisition by eukaryotic phytoplankton, Limnol. Oceanogr., 50, 872-882, 2005.

Silsbe, G. M. and Kromkamp, J. C.: Modeling the irradiance dependency of the quantum efficiency of photosynthesis, Limnol. Oceanogr.-Methods, 10, 645-652, 2012.
Sokolov, S. and Rintoul, S. R.: On the relationship between fronts of the Antarctic Circumpolar Current and surface chlorophyll concentrations in the Southern Ocean, J. Geophys. Res., 112, C07030, doi:10.1029/2006JC004072, 2007.

Sosik, H. M. and Olson, R. J.: Phytoplankton and iron limitation of photosynthetic efficiency in the Southern Ocean during late summer, Deep-Sea Res. Pt. I, 49, 1195-1216, 2002.

Suga, T., Motoki, K., Aoki, Y., and Macdonald, A. M.: The North Pacific climatology of winter mixed layer and mode waters, J. Phys. Oceanogr., 34, 3-22, 2004.

Suggett, D. J., MacIntyre, H. L., and Geider, R. J.: Evaluation of biophysical and optical determinations of light absorption by photosystem II in phytoplankton, Limnol. Oceanogr.-Methods, 2, 316-332, 2004.

Suggett, D. J., Moore, C. M., Hickman, A. E., and Geider, R. J.: Interpretation of fast repetition rate (FRR) fluorescence: signatures of phytoplankton community structure versus physiological state, Mar. Ecol.-Prog. Ser., 376, 1-19, 2009.

Sunda, W. G.: Feedback Interactions between Trace Metal Nutrients and Phytoplankton in the Ocean, Front. Microbiol., 3, 204, doi:10.3389/fmicb.2012.00204, 2012.

Thomson, R. E. and Fine, I. V.: Estimating mixed layer depth from oceanic profile data, J. Atmos. Ocean. Tech., 20, 319-329, 2003.

Trees, C. C., Clark, D. K., Bidigare, R. R., Ondrusek, M. E., and Mueller, J. L.: Accessory pigments versus chlorophyll a concentrations within the euphotic zone: A ubiquitous relationship, Limnol. Oceanogr., 1130-1143, 2000.

Vassiliev, I. R., Kolber, Z., Wyman, K. D., Mauzerall, D., Shukla, V. K., and Falkowski, P. G.: Effects of iron limitation on photosystem-II composition and light utilization in Dunaliellatertiolecta, Plant Physiol., 109, 963-972, 1995.

Venables, H. and Moore, C. M.: Phytoplankton and light limitation in the Southern Ocean: Learning from high-nutrient, high-chlorophyll areas, J. Geophys. Res.-Oceans, 115, C02015, doi:10.1029/2009JC005361, 2010.

Walker, N. D.: Satellite-observations of the Agulhas Current and episodic upwelling south of Africa, Deep-Sea Res. Pt. a, 33, 1083-1106, 1986.

Woodward, E. M. S. and Rees, A. P.: Nutrient distributions in an anticyclonic eddy in the North East Atlantic Ocean, with reference to nanomolar ammonium concentrations, Deep-Sea Res. Pt. II, 48, 775-794, 2001.

Yentsch, C. S. and Phinney, D. A.: A bridge between ocean optics and marine ecology, Limnol. Oceanogr., 34, 1694-1705, 1989.

Zubkov, M. V., Fuchs, B. M., Tarran, G. A., Burkill, P. H., and Amann, R.: High rate of uptake of organic nitrogen compounds by Prochlorococcus cyanobacteria as a key to their dominance in oligotrophic oceanic waters, Appl. Environ. Microb., 69, 1299$1304,2003$. 